\title{
Large-scale salmon farming in Norway impacts the epiphytic community of Laminaria hyperborea
}

\author{
Barbro Taraldset Haugland ${ }^{1,2, *}$, Caroline S. Armitage ${ }^{1}$, Tina Kutti ${ }^{1}$, Vivian Husa ${ }^{1}$, \\ Morten D. Skogen ${ }^{1}$, Trine Bekkby ${ }^{3}$, Marcos A. Carvajalino-Fernández ${ }^{1}$, Raymond J. \\ Bannister $^{1}$, Camille Anna White ${ }^{4}$, Kjell Magnus Norderhaug ${ }^{1,2}$, Stein Fredriksen ${ }^{1,2}$ \\ ${ }^{1}$ Institute of Marine Research, PO Box 1870, Nordnes, 5817 Bergen, Norway \\ ${ }^{2}$ Department of Biosciences, Section for Aquatic Biology and Toxicology, PO Box 1066, Blindern, 0316 Oslo, Norway \\ ${ }^{3}$ Section for Marine Biology, Norwegian Institute for Water Research, 0349 Oslo, Norway \\ ${ }^{4}$ Institute for Marine \& Antarctic Studies, University of Tasmania, Taroona 7053, Tasmania, Australia
}

\begin{abstract}
Large-scale finfish farms are increasingly located in dispersive hard-bottom environments where Laminaria hyperborea forests dominate; however, the interactions between farm effluents and kelp forests are poorly understood. Effects of 2 levels of salmonid fish-farming effluents (high and low) on L. hyperborea epiphytic communities were studied by sampling canopy plants from 12 sites in 2 high-energy dispersive environments. Specifically, we assessed if farm effluents stimulated fast-growing epiphytic algae and faunal species on L. hyperborea stipes - as this can impact the kelp forest community composition - and/or an increased lamina epiphytic growth, which could negatively impact the kelp itself. We found that bryozoan biomass on the stipes was significantly higher at high-effluent farm sites compared to low-effluent farm and reference sites, resulting in a significantly different epiphytic community. Macroalgal biomass also increased with increasing effluent levels, including opportunistic Ectocarpus spp., resulting in a less heterogeneous macroalgae community at high-effluent farm sites. This habitat heterogeneity was further reduced by the high bryozoan biomass at the high-effluent sites. Such changes in the epiphyte community could have implications for the faunal community that relies on the epiphytes for food and refuge. On the kelp lamina, no clear response to farm effluents was found.
\end{abstract}

KEY WORDS: Laminaria hyperborea $\cdot$ Kelp $\cdot$ Epiphytes · Epiphytic community $\cdot$ Salmo salar Atlantic salmon $\cdot$ Norway $\cdot$ Bryozoa

\section{INTRODUCTION}

Increased loading of nutrients from anthropogenic activities can be a driver of ecosystem change in coastal hard-bottom systems (e.g. Filbee-Dexter \& Wernberg 2018) and has in some cases contributed to slow-growing perennial macrophytes such as kelp forests being replaced by fast-growing ephemeral algae mats (e.g. Kraufvelin et al. 2006, Worm \& Lotze 2006, Filbee-Dexter \& Wernberg 2018). Along the Norwegian coast, salmonid fish farming is currently the largest anthropogenic source of nutrients in coastal waters, contributing $55 \%$ of the total anthro-

\footnotetext{
${ }^{*}$ Corresponding author: barbro.haugland@gmail.com
}

pogenic nitrogen emissions (Selvik \& Sample 2018). However, the interactions between nutrient effluents from fish farming and kelp forests are poorly understood. Kelp forests face several stressors, such as sea urchin overgrazing, climate change, and harvesting (reviewed by Steneck et al. 2002, Araújo et al. 2016). With more than a third of kelp forests worldwide having been in decline over the last $50 \mathrm{yr}$ (Krumhansl et al. 2016) and better management of kelp forests being called for (Teagle et al. 2017), it is imperative to discern the potential response of kelp forest ecosystems to localised increased nutrient loadings such as fish farming effluents.

(C) The authors 2021. Open Access under Creative Commons by Attribution Licence. Use, distribution and reproduction are unrestricted. Authors and original publication must be credited. 
Kelps (Laminariales) are important seaweeds in temperate coastal seas, as they provide important ecosystem services, e.g. supporting a diverse community of associated epiphytic macroalgae (e.g. Christie et al. 2003) and fauna (e.g. seabirds: Fredriksen 2003; macrofauna: Christie et al. 2003, Fredriksen 2003; fish: Norderhaug et al. 2005), having exceptionally high primary production and carbon assimilation (Charpy-Roubaud \& Sournia 1990, Steneck et al. 2002, Christie et al. 2009) with resulting kelp detritus providing a significant food source for local secondary production (Fredriksen 2003, Norderhaug et al. 2003), in addition to subsidizing other habitats in deeper waters (Krumhansl \& Scheibling 2012, Pedersen et al. 2020). Changes in our kelp forests could therefore have cascading effects on ecosystem function and services, both locally and beyond the coastal zone.

The rapid growth of the Norwegian aquaculture industry, from ca. $490000 \mathrm{t}$ in 2000 (Gullestad et al. 2011) to ca. $1340000 \mathrm{t}$ in 2018 (Fiskeridirektoratet 2019), has made Norway one of the leading countries worldwide in marine aquaculture production (FAO 2018). A continuous restructuring of the industry has followed this expansion; from small farms in sheltered fjords (3000-5000 t maximum total biomass [MTB]) to larger farms (ca. 6000-14000 t MTB) in more exposed and shallow coastal locations-locations where Laminaria hyperborea (Gunnerus) Foslie kelp forests typically thrive down to a depth of ca. $30 \mathrm{~m}$ (Kain 1979, Lüning 1990, Bekkby et al. 2009). Indeed, the majority of the Norwegian aquaculture expansion over the last 10 yr can be attributed to a developing industry in the Frøya-Smøla archipelago $\left(63^{\circ} \mathrm{N}\right)$ in the county of Trøndelag, an area where L. hyperborea dominate the shallow hard-bottom habitats (Steen 2017, 2018). This current relocation together with larger farm-size is thus increasing the likelihood of impacts on L. hyperborea forests. In this specific area (and along the central and northern coast of Norway) the habitat type L. hyperborea forests is currently listed as 'near threatened' (Gundersen et al. 2018), making impact-studies on this habitat type particularly relevant. Few studies have examined the effect of salmonid fish farm effluents in exposed coastal locations or on kelp forests, with most previous work focussing on soft-bottom habitats (Holmer 2010) and fjords (Kutti et al. 2007a,b). Effluents being released from the fish farms that are located at more exposed sites are likely to be more dispersed (hence the allowance of larger farms compared to in sheltered fjords), potentially resulting in environmental responses being more diffuse and difficult to detect compared to in-fjord systems. Future expansion of the aquaculture industry, both in Norway and globally, will include further relocations to exposed, dispersive coastal environments due to the observed higher resilience of soft-bottom habitats at such locations (Keeley et al. 2013, 2019, Valdemarsen et al. 2015), increasingly overlapping with kelp forest habitats, making it critical to quantify any potential effects aquaculture effluents may have on kelp forest conditions.

Fish farming releases large amounts of effluents in the form of dissolved nutrients and particulate organic matter (POM), which have the potential to affect kelp forests, both directly and indirectly. The amount of these effluents released along the Norwegian coast in 2018 was estimated by Husa (2019) to be $52000 \mathrm{t}$ of dissolved inorganic nitrogen (DIN) (mainly ammonia; e.g. Sanderson et al. 2008), $7000 \mathrm{t}$ of dissolved inorganic phosphorus (DIP) (Husa 2019), and 540000$670000 \mathrm{t}$ of POM (Hansen 2019). Effluent amount and dispersal from individual farms will depend on the farm characteristics (biomass and feed levels, related to the stage of the production cycle) and location (i.e. the depth, wave exposure, and current strength and direction at the site) (Jansen et al. 2016). DIN is most likely to become a limiting nutrient for seaweed growth in undisturbed temperate coastal waters (and DIP in freshwater systems) (e.g. Kain 1989, Howarth \& Marino 2006), especially in the warm summer months following the spring bloom (Rey 2004), which is when effluent release from fish farms tends to be highest (Wang et al. 2012). Ephemeral macroalgae, many of which grow as epiphytes on kelp, can respond faster to increased nutrient availability than perennial slow-growing macroalgae (Pedersen \& Borum 1996). Ephemeral macroalgae also grow during summer, with L. hyperborea stipe and lamina epiphyte biomass peaking in August (Christie et al. 2003), whereas the main growth season for Laminariales is during winter and early spring (Kain 1979). Hence, although fish-farm derived DIN may have a positive effect on kelp, fast-growing ephemeral algae are thought to benefit more, and an increase in epiphytic algae growth on perennial macrophytes with nutrient enrichment is well documented (e.g. Rönnberg et al. 1992, Worm \& Sommer 2000, Oh et al. 2015).

Some degree of epiphytic fouling on kelp laminae is common in natural communities and tends to decrease with increasing wave exposure (Jorde 1966, Pedersen et al. 2012). However, increased lamina epiphytic load can reduce growth and survival of kelp (Levin et al. 2002) by affecting the kelp's photosynthetic performance and nutrient uptake (Andersen et al. 2011) and can reduce the light available to the kelp by $90 \%$ (Andersen et al. 2019). Epiphytic fil- 
ter feeders (e.g. bryozoans and colonial tunicates) are common on kelp and may benefit from increased nutrients (both in the form of DIN and POM), and an increase in epiphytic bryozoan cover has been observed for Mediterranean seagrass communities with increasing nutrients (Balata et al. 2010). Encrustation by bryozoans can weaken the kelp lamina, leaving it more prone to breakage (Krumhansl et al. 2011). Enhanced epiphytic load on L. hyperborea stipes can result in an increased habitat complexity of the kelp forest, but nutrient enrichment tends to homogenize communities (Balata et al. 2010, Oh et al. 2015). As positive relationships between epiphytes and faunal abundance are present on large macrophytes (Christie et al. 2003, 2009, Norderhaug et al. 2014, Armitage \& Sjøtun 2016), such changes in the epiphytic community could have knock-on effects on ecosystem functioning via changes to the faunal community.

The aim of this study was to assess the effect of 2 levels (high and low) of effluents (DIN and POM) from largescale salmonid fish farms in dispersive environments on L. hyperborea forest functioning. Specifically, we assessed if the amount of epiphytes (macroalgae, colonial tunicates, and bryozoans) living on the kelp stipe and lamina increased as a response to fish farm effluents, and if the community structure of the stipe epiphytes changed.

\section{MATERIALS AND METHODS}

\subsection{Sampling sites}

We chose 12 sites for this study: 6 sites near salmonid fish farms (FF) and 6 reference sites (Ref) located in the same area, but considered unaffected from effluents. Sites were chosen in 2 archipelagic areas on the west coast of Norway, about $40 \mathrm{~km}$ apart: Frøya (3 Ref, 3 FF) and Smøla (3 Ref, 3 FF) (Fig. 1). This part of the coast is characterized by ocean swells, waves and strong currents resulting in a highly dynamic area. The terrain in this area is mostly hard-bottom mixed with shell sand, with Laminaria hyperborea dom- inating the sublittoral rocks down to about $30 \mathrm{~m}$ (Steen 2017, 2018). Salinity ranges from 31 to $34 \%$ (IMR 2017). Both areas are subject to a high intensity of fish farming, producing more than $420000 \mathrm{t}$ of salmonid biomass in our sampling year of 2015 (Fiskeridirektoratet 2019). A typical farm cycle lasts 12-18 mo, with the farms in the present study having cycles around 18 mo (excluding the fallowing period). At the time of the study, farms in Frøya were early in the production cycle (Month 5-6), with low fish biomass and feed levels (FF-L). Farms in Smøla were at the end of their production cycle (ca. Month 17), with
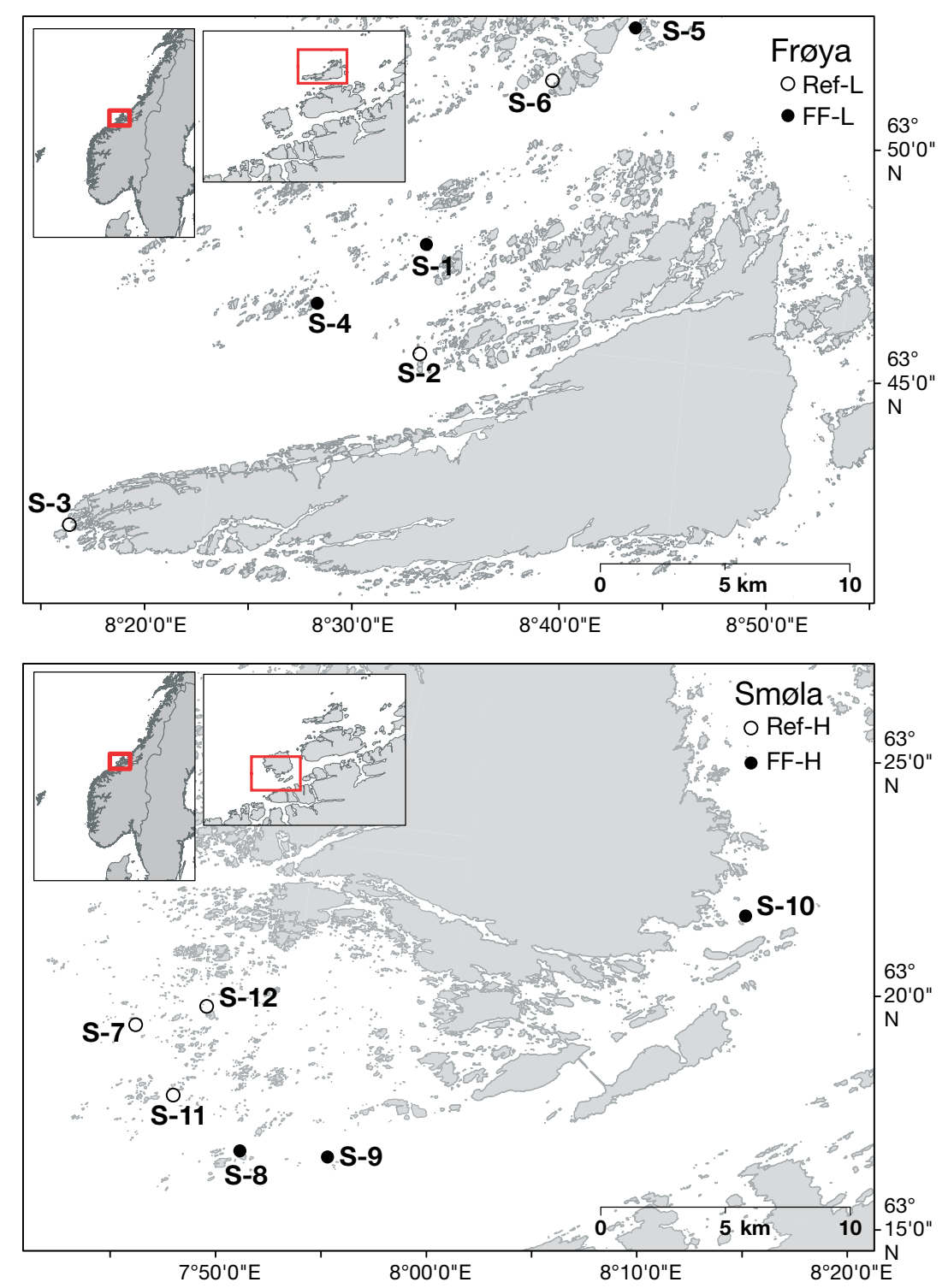

Fig. 1. Location of sampling sites in the 2 archipelagic study areas: Frøya and Smøla, Norway. Laminaria hyperborea kelp canopy plants were collected along transects at $5 \mathrm{~m}$ depth at 3 reference sites (Ref) and 3 salmonid fish farm sites (FF) in each area. FF-L and FF-H denote fish farms with low and high effluent loads at the time of sampling, respectively 
Table 1. Overview of sampling sites for Laminaria hyperborea kelp plants collected from salmonid fish farming (FF) sites (low effluent load: FF-L, high effluent load: FF-H) and reference sites (Ref-L, Ref-H) in the Frøya (Ref-L, FF-L) and Smøla (Ref-H, FF-H) archipelagos, Norway, August 2015. Information is also given on the maximum total fish biomass (MTB) permitted at the farm, the mean amount of feed-use at farms for the 6 mo prior to sampling (January-July 2015), and the distance to the nearest farm

\begin{tabular}{|lcccc|}
\hline Site & Group & $\begin{array}{c}\text { MTB } \\
(\mathrm{t})\end{array}$ & $\begin{array}{c}\text { Mean feed } \\
\left(\mathrm{kg} \mathrm{mo}^{-1}\right)\end{array}$ & $\begin{array}{r}\text { Distance } \\
\text { to farm (m) }\end{array}$ \\
\hline Frøya & & & & \\
S-1 & FF-L & 10920 & 122000 & 380 \\
S-2 & Ref-L & & & 3850 \\
S-3 & Ref-L & & & 21600 \\
S-4 & FF-L & 8580 & 131000 & 60 \\
S-5 & FF-L & 7800 & 79000 & 200 \\
S-6 & Ref-L & & & 2890 \\
Smøla & & & & \\
S-7 & Ref-H & & & 7100 \\
S-8 & FF-H & 8580 & 857000 & 150 \\
S-9 & FF-H & 6240 & 466000 & 200 \\
S-10 & FF-H & 5460 & 577000 & 520 \\
S-11 & Ref-H & & & 3530 \\
S-12 & Ref-H & & & 6020 \\
\hline
\end{tabular}

high fish biomass and feed levels (FF-H). Mean monthly feed use at the FF-H farms was 3.5-11 times higher than at the FF-L farms in the 6 mo preceding sampling (Table 1).

Sampling in both areas gave the opportunity to compare the effects of a high versus a low effluent load while at the same time assessing whether potential impacts were short term (i.e. if impacts were only observed at FF-H sites and not FF-L sites) or long term (i.e. if the same level of impacts was found at both FF-H and FF-L sites), as the effluent load level varies with farm cycle stage. Wave exposure levels differed between the FF locations, hence, to take the potential effect of wave exposure into account, the study location at Ref sites was chosen based on 2 criteria: similar wave exposure levels as the FF locations and $>2 \mathrm{~km}$ from any fish farm or other major industries. Due to wave-exposure and ocean current patterns in the sampling area, the impact of effluents is not believed to follow a clear gradient as in calm fjords (Kutti et al. 2007a,b), but rather, impacts are evident in patches in the prevailing current direction (particle modelling conducted herein), with benthic effects observed up to $1000 \mathrm{~m}$ away (Keeley et al. 2019). Thus, within each study location, a skerry with L. hyperborea forest was chosen as the sampling site, itself based on 2 criteria: presence of $L$. hyperborea forest at $5 \mathrm{~m}$ depth (relative to the nautical chart zero, i.e. the lower astronomical tide [LAT]), as depth can have an impact on kelp communities (Kain 1977), and that the skerry was located within the main effluent plume of the farm. To ensure that $L$. hyperborea plants at FF locations were sampled from effluent-impacted kelp forest, the direction of the main effluent plume was determined from ocean current models, and the closest suitable skerry to the farm within the plume was selected as the sampling site. Maps of modelled particle movement and dissolved nutrients were consulted after the study to check that the farm sites were in the area of effect of the farm (see Section 2.5 for details, and see Figs. $3 \& 4$ ).

\subsection{Sampling design}

Sampling was conducted over 6 consecutive days, from 8 to 14 August 2015, the time of year when epiphyte abundance on $L$. hyperborea normally peaks (Christie et al. 2003). At each site, a $25 \mathrm{~m}$ transect was laid out along the sea floor, following contours so the depth remained at $5 \mathrm{~m}$ LAT. The living canopy plant closest to the metre mark every $2 \mathrm{~m}$ for $20 \mathrm{~m}$ was collected by SCUBA divers, giving a total of 10 thalli (holdfasts were collected along the last $5 \mathrm{~m}$ of the $25 \mathrm{~m}$ transect; B. T. Haugland unpubl.). The density of the L. hyperborea forest was determined by counting the number of living canopy thalli within 5 randomly selected $1 \mathrm{~m}^{2}$ quadrants along the transect. Collected L. hyperborea plants were kept in fresh seawater until processed. The thallus of each collected plant was divided into lamina and stipe, where the lamina was cut off $1 \mathrm{~cm}$ below the stipe-lamina transition zone, and the stipe right above the holdfast-stipe transition zone. A summary of sampled kelp variables is given in Table S1 in the Supplement at www.int-res.com/ articles/suppl/q013p081_supp.pdf.

\subsection{Stipe measurements and epiphytes}

Epiphytic macroalgae and fauna were collected by scraping them off the stipe; samples were frozen until processed in the laboratory at the Institute of Marine Research in Bergen, Norway. Large bundles of Desmarestia aculeata were occasionally tangled around the top of the stipe, or a second L. hyperborea (typically several years old) was growing out from the sampled thallus. These were identified and weighed in situ but excluded from further data analysis. To determine the area available for epiphytic growth, the surface area (SA) of the stipes was calculated by recording 
the length and the diameter at the top and bottom of the stipe. As stipes can be oval in cross-section, the diameter was measured twice perpendicular to each other, and the average was used. Grazing by urchins was common in the study area (75-100\% of the stipe epiphytes were grazed in most samples), distinguished by short stubble left on the stipe, in most cases the bottom section (see Fig. 2 for comparison). Stipe epiphyte biomass was therefore standardized to $10 \mathrm{~cm}^{2}$ ungrazed SA to allow comparisons across sites independent of stipe length, and as grazing would reduce epiphyte biomass irrespective of the effect of farm effluents on epiphyte growth. Grazed SA was calculated using the same method as for stipe SA (using the diameters of the upper and lower grazing boundary and length of the grazed stipe) where whole sections of the stipe had been grazed, which was mostly the case. When grazing was patchy or inconsistent along the stipe, a percentage in relation to total stipe SA was estimated to the nearest $10 \%$. Stipe age was determined by counting growth rings (Kain 1963).

To study changes in biomass and community structure, epiphytic macroalgae $>0.5 \mathrm{~cm}$ in length were defrosted in the laboratory and identified to the lowest possible taxonomic level (genus, species) by the use of relevant literature (Dixon \& Irvine 1977, Rueness 1977, Prud'homme van Reine 1982, Irvine 1983, Fletcher 1987, Maggs \& Hommersand 1993, Irvine \&
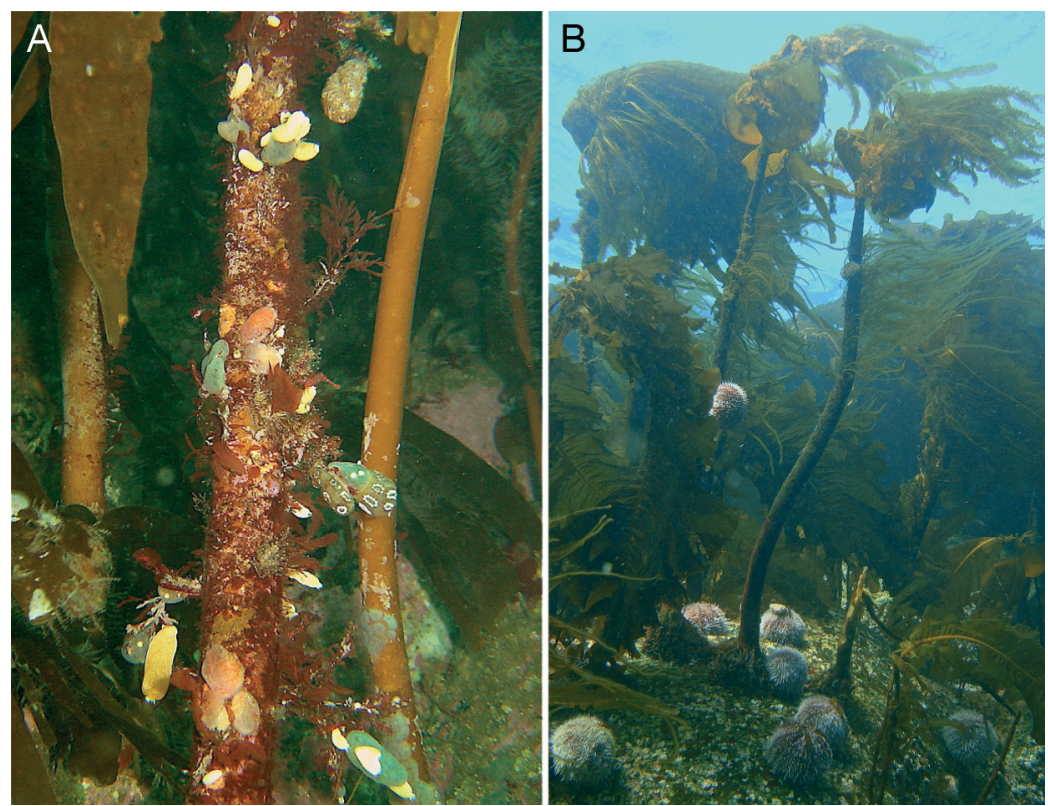

Fig. 2. Examples of typical stipe epiphytic communities found on Laminaria hyperborea. (A) Well-developed epiphytic community on a canopy plant and a young stipe with little epiphytic macroalgae growth. (B) Grazing by the sea urchin Echinus esculentus on the stipe, especially on the epiphytes on the bottom half. Photo by Stein Fredriksen
Chamberlain 1994, Brodie et al. 2007). The biomass of each species was determined (fresh weight, FW) after spinning the sample in a salad spinner for 5 rounds to remove excess water. Freezing and defrosting have little impact on distinguishing features of macroalgae. The biomass may be slightly reduced due to cells breaking and consequently leaking, but this was not observed. Macroalgae $<0.5 \mathrm{~cm}$ were grouped and blotted to determine FW and included in the univariate analysis of total biomass. Bryozoans (encrusting [thin sheets] and erect [plant-/bush-like]), and macroalgae which had bryozoans covering $>40 \%$ of their surface, were grouped as 'Bryozoa'. These were not identified further, as different bryozoan species were frequently overgrowing each other. One level of epiphytic growth was identified and quantified (except in the case of bryozoans); small epiphytic algae that were loosely attached to the epiphytic community were occasionally observed but were excluded due to uncertainty regarding whether they were actually part of the attached community or simply drifting seaweed that had become entangled.

\subsection{Lamina measurements and epiphytes}

The biomass (FW) and maximum length of the lamina were recorded after removal of epiphytes. Presence of dominant epiphytes was quantified using different methods depending on the group: SA for encrusting colonyforming fauna (bryozoans and tunicates); number of colonies for erect bryozoans; and biomass (FW) for macroalgae. SA and the number of erect colonies were determined by laying the lamina out on a flat surface and taking photographs. Five randomly selected photographs from each site were later processed using the program ImageJ (Schneider et al. 2012) by tracing the edge of the lamina and subsequently the edge of the attached fauna. Macroalgae were gently scraped off the lamina and frozen until processing in the laboratory at the Institute of Marine Research in Bergen. Lamina macroalgae were sorted in the following categories to assess changes in biomass of dominant macroalgae groups: Rhodophyta leaf-forming, Rhodophyta branched (Polysiphonial Ceramium-like), Ectocarpales thread 
(thin Ectocarpus-like filaments), and Ulvales. Biomass in FW was determined in the same way as the stipe epiphytes.

\subsection{Modelling of abiotic variables and farm effluents}

Site information on abiotic data, particle settlement, and DIN was made available from different models (see Table S1 for summary of abiotic data used).

Mean current speeds for analysis were taken from the NorKyst800 model (Albretsen et al. 2011, Asplin et al. 2020 ) interpolated onto a $500 \times 500 \mathrm{~m}$ grid. In addition, a higher-resolution model $(160 \times 160 \mathrm{~m})$ nested into the NorKyst800 model was run for the Frøya/Smøla area. Both models are based on the Regional Ocean Modelling System (ROMS, www.myroms.org; Shchepetkin \& McWilliams 2005). Realistic forcing of the ocean model from atmosphere, tides, and rivers are included as described by Asplin et al. (2014). The NorKyst800 model has been validated (e.g. Asplin et al. 2020).

The higher-resolution circulation fields from the ROMS model were also used to force the Lagrangian transport model LADiM (Ådlandsvik 2019), to predict the transport of particle waste from the FF in the study area and verify whether the sampling sites were located within the effluent plume of the nearby farm. LADiM calculates active transport of individual particles using the modelled currents as inputs, as well as particle-specific dynamics including settling and lifespan via an individual-based model. Constant settling velocity of $7.5 \mathrm{~cm} \mathrm{~s}^{-1}$ and a particle lifespan of approximately $12 \mathrm{~d}$ were used as model parameters based on previous research (Bannister et al. 2016, Carvajalino-Fernández et al. 2020). Particle distribution at the sampling sites was calculated and presented as particle accumulation maps in order to identify the plume trajectories for the periods of interest.

Using sampling to adequately capture the effect of FF effluents on dissolved nutrient concentrations can be extremely challenging, due to the high spatialtemporal variation and utilization/transformation (Jansen et al. 2016). Hence the NORWECOM model (Skogen et al. 1995, Skogen \& Søiland 1998) was used to predict the dispersion and ambient concentrations of DIN at the sampling sites. The NORWECOM model is a full 3-dimensional nutrientphytoplankton-zooplankton-detritus model, and the processes included are primary and secondary production, grazing, respiration, algae death, remineralization of inorganic nutrients from dead organic matter, self-shading, turbidity, sedimentation, resus- pension, sedimental burial, and denitrification. The model has been validated (e.g. Skogen et al. 1997, Søiland \& Skogen 2000, Hjøllo et al. 2009). This model takes physical forcing from the $160 \times 160 \mathrm{~m}$ ROMS model as inputs. To highlight the effect of FF effluents on natural DIN levels at all 12 sampling sites, the difference in predicted DIN concentrations between 2 simulations are presented (see Fig. 3): 1 reference simulation with no FFs present (i.e. background DIN levels), and 1 simulation including nutrient inputs from the 6 study farms. The amount of DIN (ammonium, nitrate, and nitrite) released from the 6 farms (nutrient inputs for the second simulation) were calculated based on monthly feed data by using conversion estimates from the ANCYLUS model (Bergheim \& Braaten 2007, Husa et al. 2016). Predicted concentrations were extracted daily for all sites.

As the ROMS model does not include waves, wave exposure $\left(\mathrm{m}^{2} \mathrm{~s}^{-1}\right)$ was modelled at high spatial resolution $(25 \mathrm{~m})$ using data on fetch (distance to nearest shore, island, or coast), averaged wind speed, and wind frequency (Isæus 2004). This model has previously been applied to the whole Norwegian coast by the National program for mapping biodiversity-coast (Bekkby et al. 2013), as well as in several research projects in Norway (e.g. Bekkby et al. 2009, 2014, Norderhaug et al. 2012, 2014, Pedersen et al. 2012) and other countries (e.g. Eriksson et al. 2004, Wijkmark \& Isæus 2010).

Finally, to obtain high-resolution data on light exposure, light was calculated at a spatial resolution of $25 \mathrm{~m}$ as the deviance from an optimal influx of light based on estimates of vertical slope and orientation (aspect). This index was originally developed for terrestrial vegetation (Parker 1988); discussed and developed further by Økland (1990, 1996), and is suitable for use in the shallow-most areas of marine environments (e.g. to model kelp distribution, Bekkby et al. 2009), to provide a proxy for the variation in light condition caused by a combination of light influx and terrain shade. The light exposure is optimal (index value $=1$ ) at a slope of $45^{\circ}$ and an orientation of $202.5^{\circ}$ (Økland 1990, 1996). Considering the orientation, the index is positive at $202.5 \pm 90^{\circ}$ (with light coming in from the southwest) and negative at $22.5 \pm 90^{\circ}$ (with light coming in from the northeast).

\subsection{Statistical analysis}

The lamina-associated algal epiphytes were standardized according to lamina FW, and the faunal epiphytes (encrusting and bush-forming bryozoans, and 
colony-forming tunicates) according to lamina SA. No statistical analysis was conducted for bush-forming bryozoans and colony-forming tunicates due to low abundances and large within-group variation. The stipe epiphytes (algal and bryozoan biomass) were standardized according to stipe ungrazed SA. Note that 5 stipes were recorded as $100 \%$ grazed at the same time as some epiphytic biomass was sampled (due to rounding up to nearest $10 \%$, see Section 2.3). For these, $5 \%$ of their total stipe SA was used for standardization, as this was considered a relevant margin of error.

All statistical analyses were done using $\mathrm{R}$ (R Core Team 2017) with plots created using the package 'ggplot2' (Wickham 2016). The effect of farming on the abundance of epiphytes was analysed by constructing linear mixed-effects models ( $\mathrm{R}$ package 'nlme'; Pinheiro et al. 2017). These allow for the inclusion of a random effect, 'site' (12 levels), which accounts for the potential inter-dependence of thalli sampled from the same site. The effect of farming was examined using the variable 'group' (categorical, 4 levels: Ref-L, Ref-H, FF-L, FF-H). A number of control variables were chosen for inclusion, based on biological theory that they could influence the response variables: kelp age (continuous), kelp density (continuous), wave exposure (continuous, modelled), current speed (continuous, modelled), and light (continuous, modelled). Variables were tested for collinearity by calculating the variance inflation factor (VIF) and examining pairwise correlations. All VIF values were low $(\leq 3.2 ;$ Table S2). The dataset did not allow for testing interactions between control variables and is also limited for making conclusions about the impact of these factors on epiphyte communities. One site had much higher wave exposure than the rest (Site 7, Ref- $H_{i}>2.5 \times$ higher than any other site), which could unduly influence the analyses. The analyses were therefore run once with, and once without, this site.

Before any testing, plots of residuals for the models were examined to check for homogeneity of variance and normality. To meet these assumptions, some response variables were square-root transformed, and variance structure functions were included to allow the residual variation to vary along certain variables (selected based on plots of residuals and AIC and likelihood ratio testing, following Zuur et al. 2009; see Table 2). Significance testing was done using likelihood ratio tests (comparisons of the model with and without the variable of interest, Zuur et al. 2009). To test for differences between levels of 'group', Dunnett contrasts were done, which compared a treatment (FF-H or FF-L) to controls (Ref-H and Ref-L averaged), using an approximation of the Dunnett $\mathrm{p}$-value adjustment for multiple comparisons (R package 'lsmeans'; Lenth 2016). After analysis, the epiphytic algae were grouped by morphology (corticated, foliose, uniseriate, other; Karez et al. 2004), and by higher taxon (Rhodophyta, Phaeophyceae, Chlorophyta) to visually explore any shifts correlating with FF effluents.

Non-metric multi-dimensional scaling (NMDS) was chosen to graphically present the stipe epiphytic community. NMDS ordination plots (2-dimensional) were applied to a Bray-Curtis distance matrix calculated from species biomass data (R package 'vegan'; Oksanen et al. 2018). The data were first square-root transformed to prevent very abundant species having an overwhelming effect, and stipes with a total biomass of zero were omitted (Clarke \& Warwick 2001). Vectors of scaled control variables (kelp age, kelp density, wave exposure, current speed, and light) were generated utilizing data positioning obtained in the NMDS ('envfit' function). Relative lengths of vectors correspond to their strength (i.e. magnitude of change and variability) in the positioning of samples relative to each other in NMDS plots and can thus be used to aid in NMDS interpretations. The significance of vectors and the a priori set 'group' were tested via 999 permutations. Vector fitting was conducted both with and without the high wave exposure site (Site 7). Ellipses representing $95 \%$ confidence intervals around the centroid for each level within group (Ref-L, FF-L, Ref$\mathrm{H}, \mathrm{FF}-\mathrm{H}$ ) were plotted to aid graphical representation ('ordiellipse' function), where a shift in centroid location indicates a different species composition.

To test if the stipe community composition differed between levels within group, a pairwise PERMANOVA was run (R package 'pairwiseAdonis'; Martinez Arbizu 2017). A 5-way PERMANOVA (R package 'vegan'; Oksanen et al. 2018) was used to test the significance of the chosen control variables on the epiphytic community, and to assess the amount of variation explained by these compared to the a priori set factor. P-values ( $\alpha=0.05$, based on 999 permutations) were adjusted for multiple testing in the pairwise PERMANOVA. SIMPER (R package 'vegan'; Oksanen et al. 2018) was run to investigate contribution of each species to potential differences between 'group' community compositions. PERMDISP, ('betadisp' function) was conducted to assess the multivariate dispersion of the stipe epiphytic community within the 4 different groups (i.e. beta-diversity), where a lower average distance to centroid indicates a more homogeneous community. Significance was determined with an ANOVA. Based on statistical results obtained so far, 
the analysis was conducted twice to assess if the observed patterns were caused by the macroalgae community, and/or caused by bryozoan biomass.

\section{RESULTS}

\subsection{DIN and abiotic variables}

The model of DIN and particle movements predicted that all farm sampling sites were within the main effluent plume of the respective farms. DIN levels in March (prior to the spring bloom) were predicted to range between 7.00 and $7.45 \mu \mathrm{mol} \mathrm{l}^{-1}$ at all sites. A lower elevation in DIN levels was predicted at FF-L sites (up to 1.4 times higher than at Ref sites) compared to FF-H sites (up to 1.8 times higher than at Ref sites) (Fig. 3). DIN levels in the study area were dynamic for the period (March to August) prior to sampling, with weekly fluctuations varying in magnitude from $0.03 \mu \mathrm{mol} \mathrm{l}^{-1}\left(7.19-7.22 \mu \mathrm{mol} \mathrm{l}^{-1}\right)$ to $4.42 \mu \mathrm{mol} \mathrm{l}^{-1}$ (2.07-6.50 $\mathrm{mmol} \mathrm{l}^{-1}$ ). However, a consistently higher DIN concentration was predicted at farm sites (FF-L, FF-H) compared to Ref sites (Ref-L, Ref-H) (FF-L: 0.01$0.30 \mu \mathrm{mol} \mathrm{l}^{-1}$ higher; FF-H: 0.07-0.40 $\mathrm{mmol} \mathrm{l}^{-1}$ higher; Fig. 3). Modelled particle trajectories predicted that farm sampling sites were located in areas with medium exposure to the particle plume (within $40-60 \%$ of the maximum registered depositions) from the respective fish farms (Fig. 4).

Modelled wave exposure levels ranged from 7206 to $700125 \mathrm{~m}^{2} \mathrm{~s}^{-1}$ across sites, which is classified from 'very sheltered' to 'exposed' according to the classification system of Davies et al. (2004). Modelled mean current speed ranged from 0 to $0.07 \mathrm{~m} \mathrm{~s}^{-1}$ across sites. The Ref-H sites all had relatively high wave exposure (Fig. S1). The modelled light exposure index ranged from -0.14 to 0.07 (with 1 being optimal).

\subsection{Stipe epiphyte biomass}

Macroalgae and bryozoans were the dominating stipe epiphytes, with a total of 67 macroalgal taxa identified, where the majority were red algae (Table S3). Sponges and non-colonial tunicates commonly grow on Laminaria hyperborea stipes (Christie et al. 2003), but the former were not observed and the latter were only sporadically observed, and therefore not included further. Average total epiphytic biomass on stipes ranged from 0.01 to $34.4 \mathrm{~g}$ FW between sites. Standardized to $10 \mathrm{~cm}^{2}$ ungrazed stipe, average macroalgal and bryozoan epiphytes were 1.25 and
0.48 g FW, respectively. Bryozoans were predominantly Membranipora membranacea, Electra pilosa, and species in the genera Scruparia and Crisia. Kelp density varied, ranging from 1 to 14 canopy plants $\mathrm{m}^{-2}$ at the sampled sites. Mean kelp density was slightly higher at reference sites (mean \pm SD, Ref-L: $9 \pm 8$, Ref-H: $7 \pm 7$ plants $\mathrm{m}^{-2}$ ) compared to farms (FF-L: $3 \pm 3$, FF-H: $5 \pm 2$ plants $\mathrm{m}^{-2}$; Table S1).

For epiphytic algae on the stipe, the biomass was higher at farm sites than at reference sites and increased with wave exposure level and kelp age (Fig. 5). Group (levels: Ref-L, FF-L [low effluent load], Ref-H, FF-H [high effluent load]) was a significant explanatory factor in the model ( $\mathrm{p}=0.014$, Table 2$)$. However, post hoc contrasts did not find significant differences between reference sites and farm sites (FF-H vs. Ref-L/H: p = 0.14, FF-L vs. Ref-L/H: $p=0.38$ ).

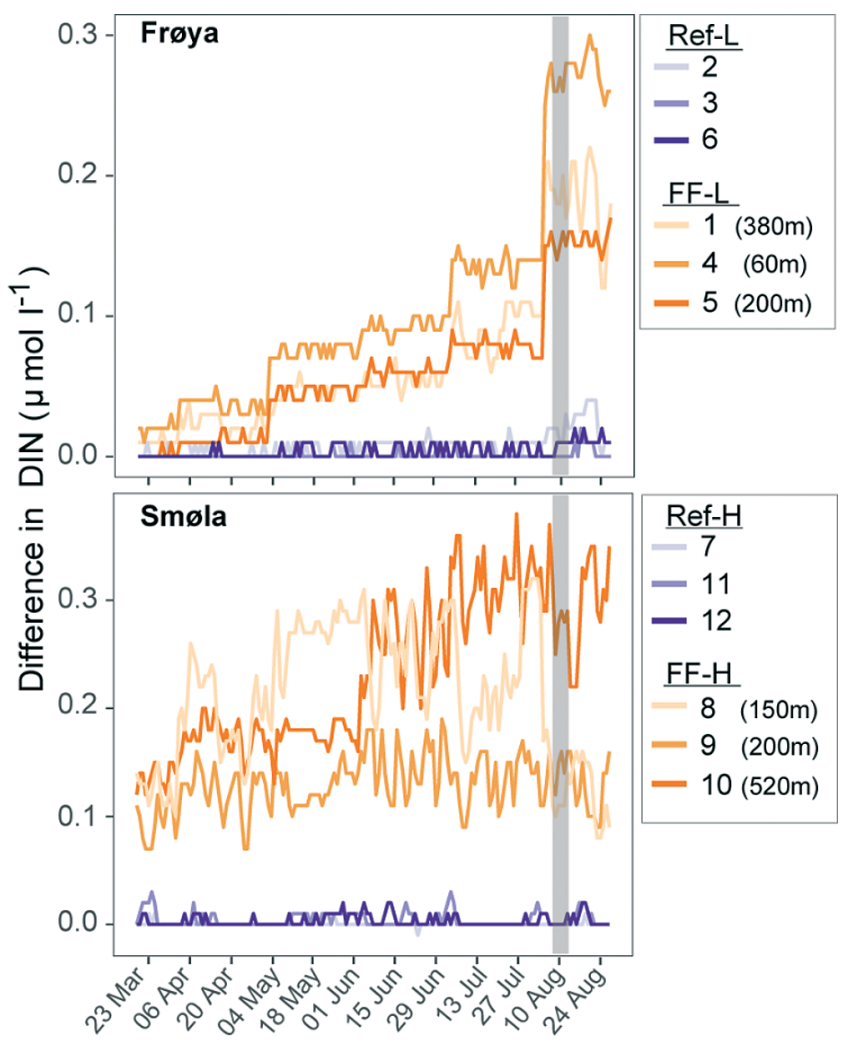

Fig. 3. Predicted effect of salmonid fish farm effluents (low levels: FF-L; high levels: FF-H) on background (reference, Ref) dissolved inorganic nitrogen concentration (DIN) in the upper $5 \mathrm{~m}$ of the water column at 3 farm sites and 3 reference sites in the Frøya (FF-L, Ref-L) and Smøla (FF-H, Ref-H) archipelagos, Norway (see Fig. 1). The difference in predicted DIN concentrations is between 2 model simulations (NORWECOM) run for 4.5 mo prior to sampling: one simulation conducted with, and one simulation without, the presence of the study farms. The grey bar marks the sampling time. For farm sites, the distance to the closest farm is included in brackets 


\section{Frøya farms}

Site 1 (FF-L) - particle movement (ocean current)

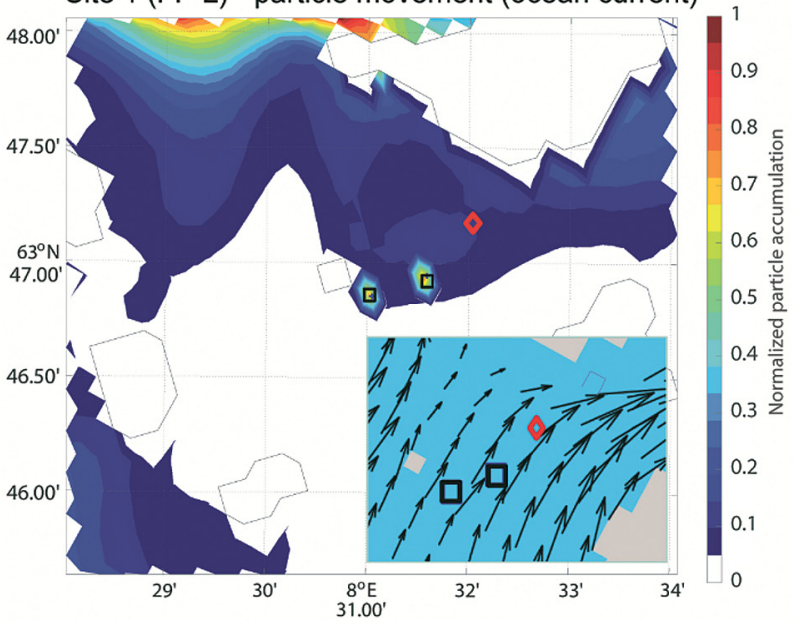

Site 4 (FF-L) - particle movement

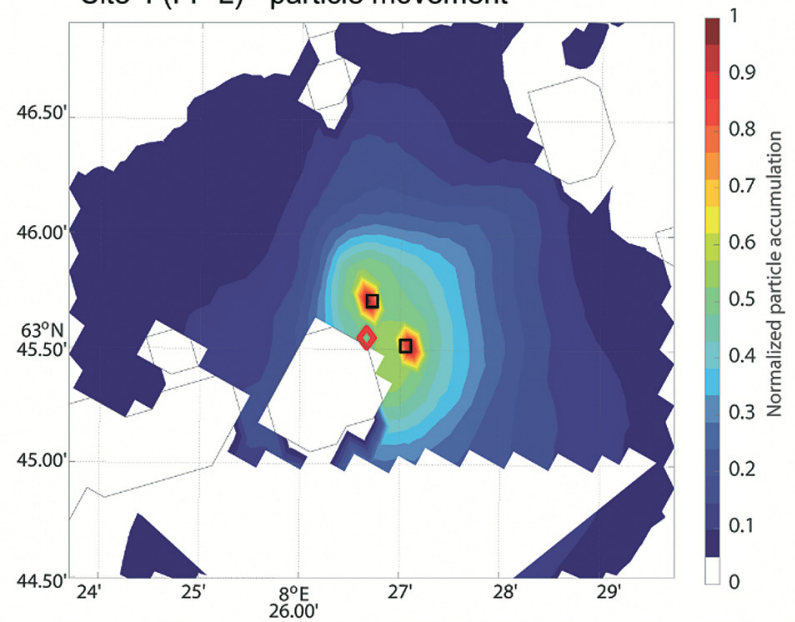

Site 5 (FF-L) - particle movement

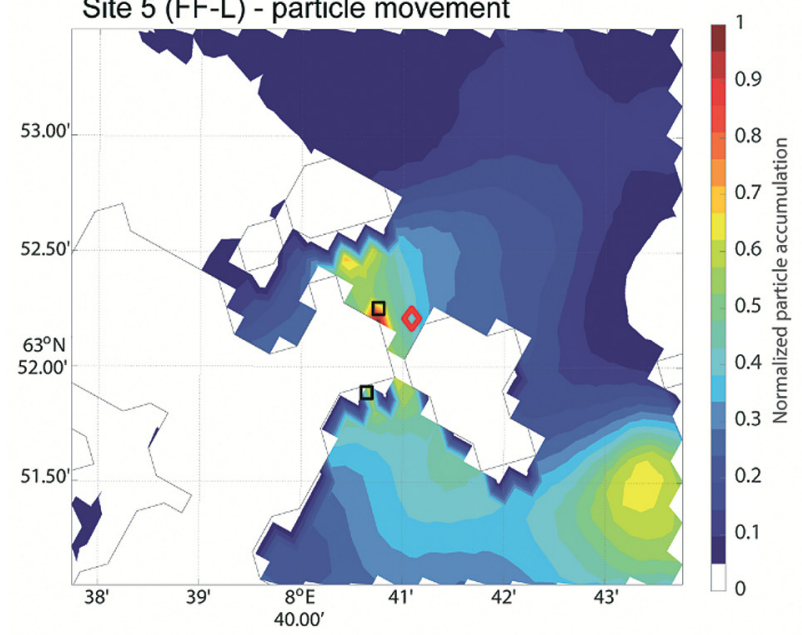

\section{Smøla farms}

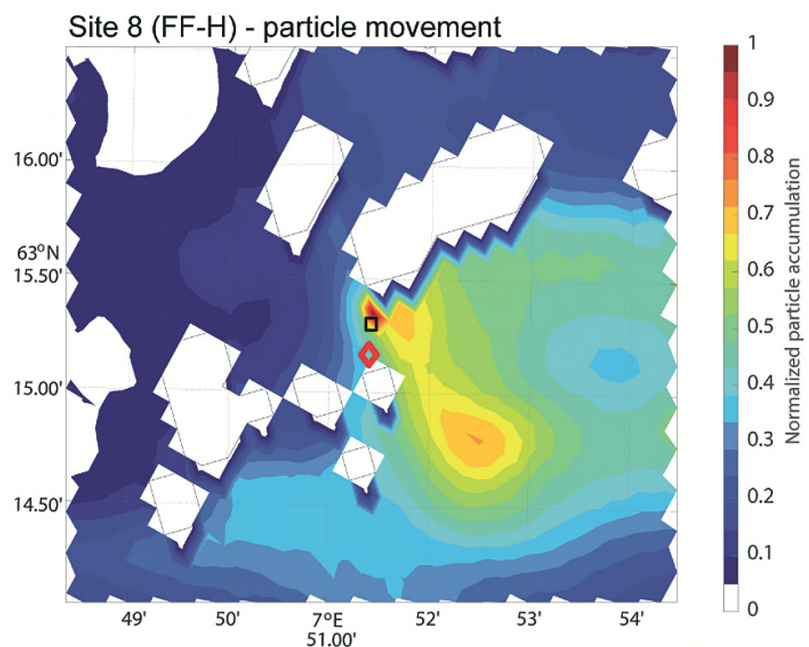

Site $9(\mathrm{FF}-\mathrm{H})$ - particle movement

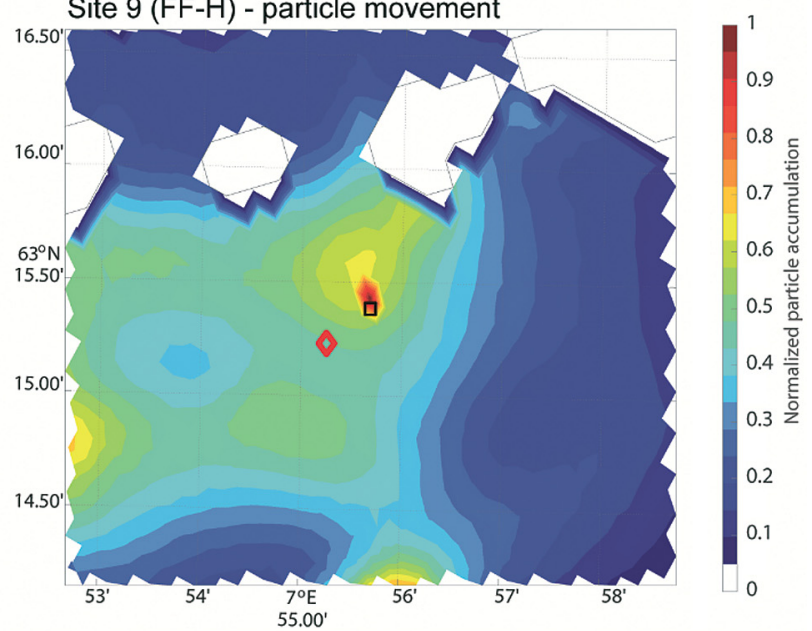

Site 10 (FF-H) - particle movement

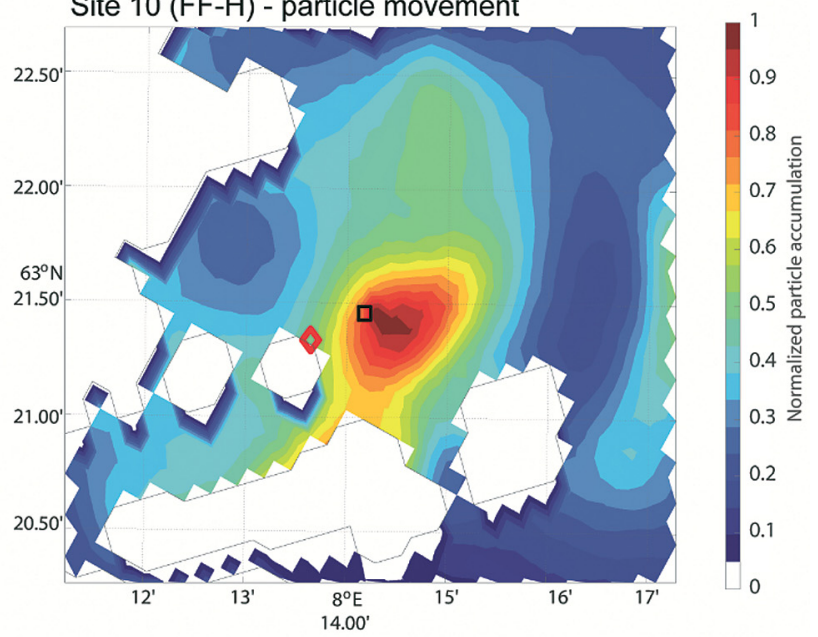

Fig. 4. Predicted effluent plume and movement of particles released from fish farms (low effluent levels: FF-L; high effluent levels: FF-H) at 3 farm sites (FF-L) located in the Frøya archipelago and at 3 farm sites (FF-H) located in the Smøla archipelago, Norway. Red diamonds are sampling sites for the collection of Laminaria hyperborea, black squares are fish farms. For Site 1, modelled ocean currents are also presented (inset), as the resolution of the particle model did not capture small skerries north of the sampling site in this specific area, resulting in an unrealistic prediction of particle movement 
Of the control variables, kelp age and wave exposure had positive significant relationships with epiphyte biomass (Table 2, Fig. S1), although the relationship with wave exposure became insignificant when the site with much higher wave exposure (Site 7) was excluded. When the macroalgal epiphytes were divided into morphological and taxonomic groups (Fig. 6),

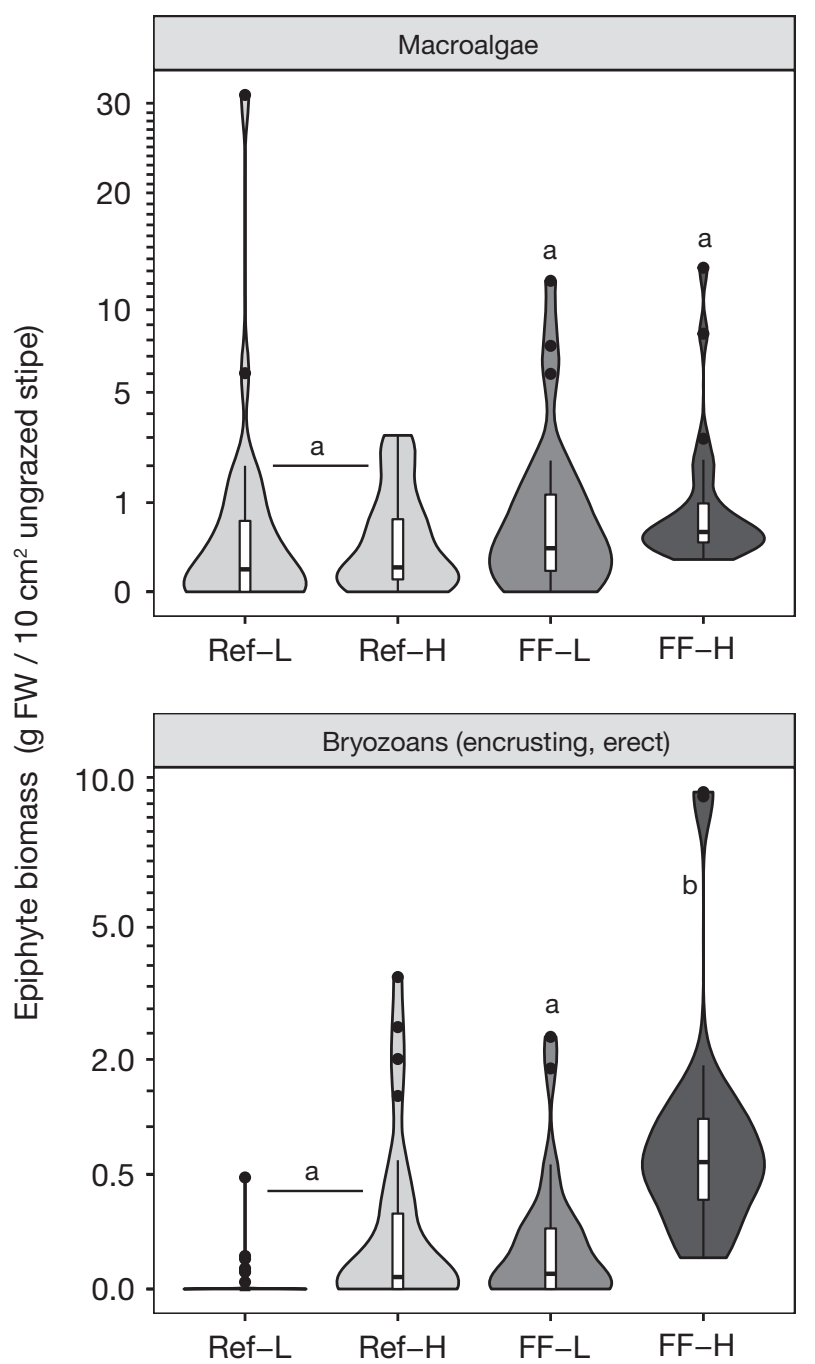

Fig. 5. Epiphytic biomass of macroalgae and bryozoans on stipes of Laminaria hyperborea kelp canopy plants collected at fish farm sites (low effluent levels: FF-L; high effluent levels: FF-H) and reference sites (Ref-L, Ref-H) in the Frøya (Ref-L, FF-L) and Smøla (Ref-H, FF-H) archipelagos, Norway. Each group consists of samples from 3 sites, each with 9-10 thalli. Note the use of different square-root scales on the $y$-axes. The distribution of the data within each group is shown by violin plots (scaled to have constant maximum widths); overlaid by boxplots showing the median, upper and lower quartiles (boxes), and the spread of the data within $1.5 \times$ the interquartile range (tails). Points represent observations outside this range. Different letters denote significant difference (Dunnett's post-hoc, $\alpha=0.05$ )

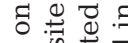

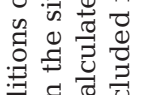

:

药 $\frac{1}{3} \cdot \pi$

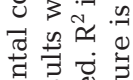

己ृ

莒

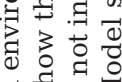

च की

ชี

究胥 응

वै.

웜

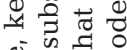

कृ थै थै

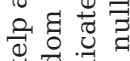

펄류

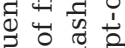

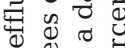

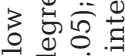

o 0 :

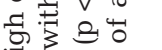

고 후웡

บ)

ब

eै, $\geq$

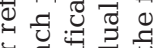

-

घี के क्ज

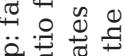

융

형뮤. 쿵

등 융

웡

记

뚜욤

먹를

讠己

(1) त्र

윰

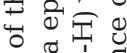

प)

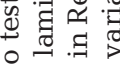

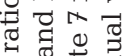

유.

焉 D

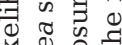

幽

4 뚱

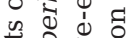

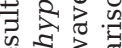

ช.

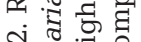

ㄱำ

영 종

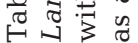

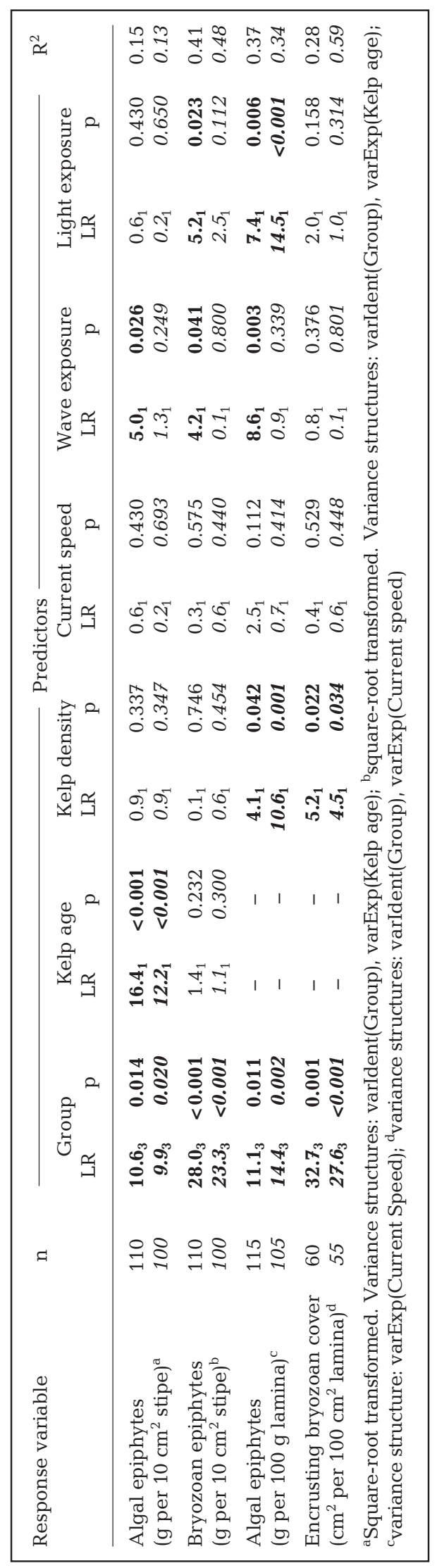


they all showed the same trend of increasing biomass with increasing effluents (except for phaeophyceans, which were constantly at very low abundances).

For epiphytic bryozoans on the stipe, the biomass increased with farm effluent load (Fig. 5), and with wave exposure level and light exposure. Group was significant ( $p<0.001$, Table 2 ), and the post hoc contrasts showed that FF-H sites had a significantly higher biomass than reference sites (FF-H vs. Ref-L/H: $\mathrm{p}=0.034$, FF-L vs. Ref-L/H: $\mathrm{p}=0.50$ ). Light exposure and wave exposure level were significantly positively related to biomass (Fig. S2), although the relationship with the latter became insignificant when the site with much higher wave exposure level was excluded (Table 2). In general, the biomass of epiphytes could be very variable between sites and between individual stipes at the same site (Fig. S3). Most stipes were heavily grazed. The lowest levels of grazing were recorded at 2 of 3 FF-H sites (Fig. S4).

\subsection{Stipe epiphyte composition}

The NMDS indicated that both the community composition and the community similarity between stipes (i.e. multivariate dispersion) were affected by farm effluents (Fig. 7). This was confirmed by the statistical analysis. The community composition on stipes in the high effluent load (FF-H) group was significantly different compared to stipes exposed to low effluent load (FF-L vs. FF-H: $p=0.008$ ) and the reference (Ref-H vs. FF-H: $p=0.006$, Table 3). SIMPER analysis revealed that this difference was primarily driven by the higher bryozoan biomass at FF-H sites. Bryozoan biomass contributed 61 and $47 \%$ to the dissimilarity between FF-H vs. Ref-H and FF-H vs. FF-L, respectively (Table 4). Among the few other species that contributed to the difference between groups, Ectocarpus spp. showed an increase in biomass with increasing effluent load, whereas there was no consistent pattern for the other contributing
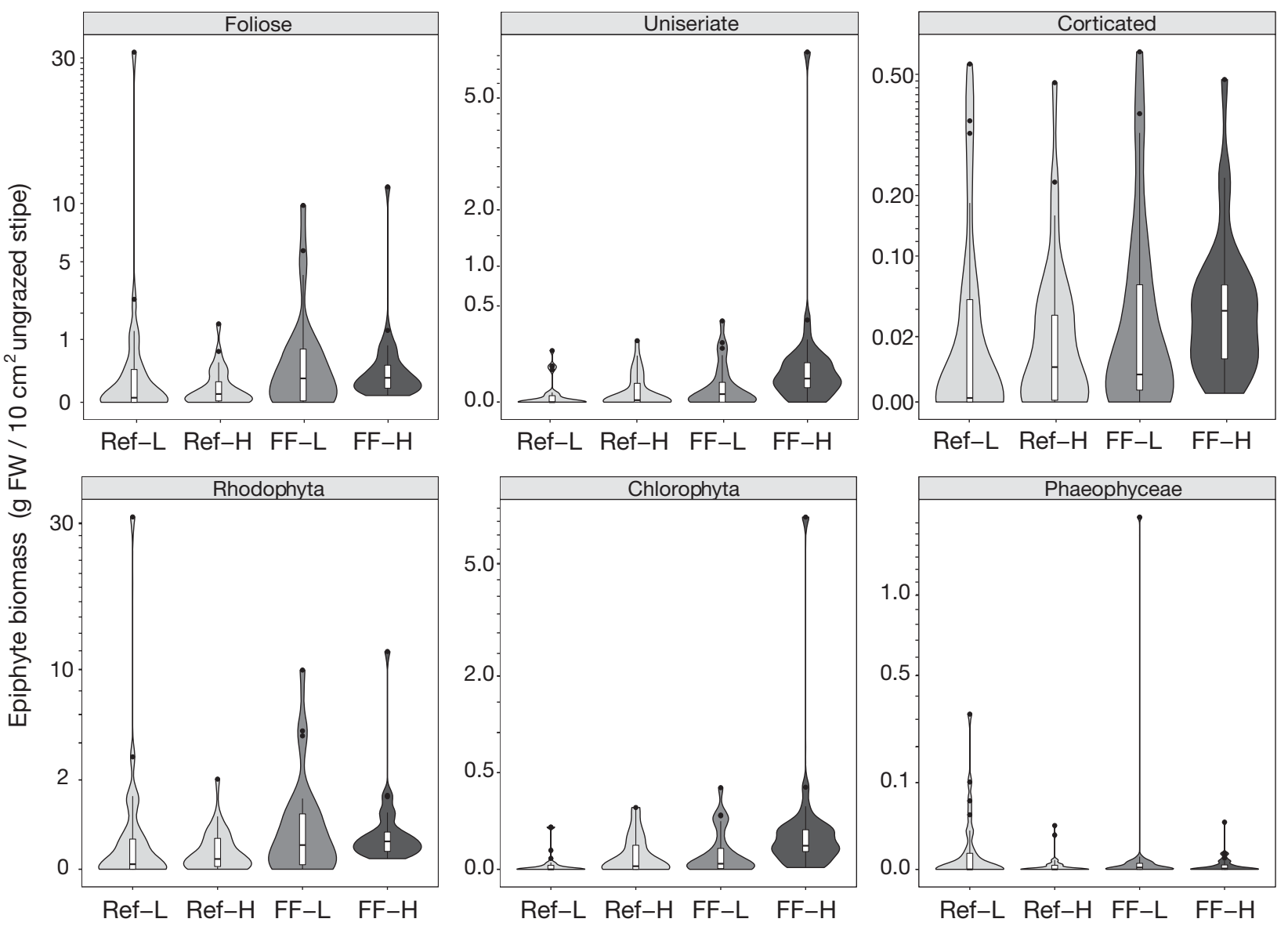

Fig. 6. Biomass of macroalgal epiphytes on stipes of Laminaria hyperborea kelp canopy plants collected at fish farm sites (low effluent levels: FF-L; high effluent levels: FF-H) and reference sites (Ref-L, Ref-H) in the Frøya (Ref-L, FF-L) and Smøla (Ref-H, FF-H) archipelagos, Norway. Epiphytes are split by morphological type and by taxonomic group. Note that the $y$-axes are on different square root scales. For plot explanation, see Fig. 5 


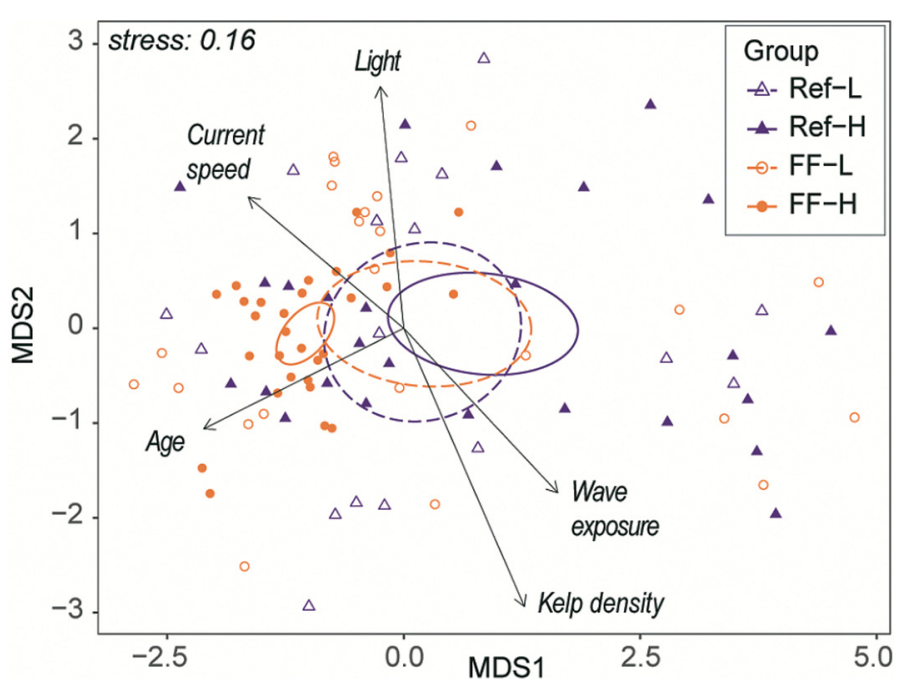

Fig. 7. NMDS of the epiphytic community on stipes of Laminaria hyperborea kelp canopy plants collected at fish farm sites (low effluent levels: FF-L; high effluent levels: FF-H) and reference sites (Ref-L, Ref-H) in the Frøya (Ref-L, FF-L) and Smøla (Ref-H, FF-H) archipelagos, Norway. The NMDS was based on Bray-Curtis similarity matrix on square-root transformed biomass ( $\mathrm{g}$ fresh weight standardized to $10 \mathrm{~cm}^{2}$ ungrazed stipe) community data. Overlaid are vectors of significant environmental variables (including Site 7, see statistical analysis and Table S4) and 95\% confidence ellipses around group centroids

Table 3. Output of PERMANOVA for the epiphytic community on Laminaria hyperborea stipes collected from fish farm sites (low effluent load: FF-L; high effluent load: FF-H) and reference sites (Ref-L, Ref-H) in the Frøya (Ref-L, FF-L) and Smøla (Ref-H, FF-H) archipelagos. The significance of chosen control variables in explaining the variation in the data, and pairwise comparisons of levels within the a priori set factor 'group', are shown ( $\mathrm{p}$-values based on permutations and adjusted for multiple testing in the former). Bold indicates significance (based on permutations, $\alpha=0.05$ )

\begin{tabular}{|c|c|c|c|c|c|c|}
\hline Control variable & df & SS 1 & Mean SS & S $\quad F$ & $\mathrm{R}^{2}$ & $\mathrm{p}$ \\
\hline Group & 3 & 3.462 & 1.154 & 4.813 & 0.13 & 0.001 \\
\hline Kelp age & 1 & 0.881 & 0.881 & 3.676 & 0.03 & 0.001 \\
\hline Kelp density & 1 & 1.172 & 1.172 & 4.888 & 0.04 & 0.001 \\
\hline Current speed & 1 & 0.616 & 0.616 & 2.570 & 0.02 & 0.002 \\
\hline Wave exposure & 1 & 0.325 & 0.325 & 1.357 & 0.01 & 0.150 \\
\hline Light exposure & 1 & 0.697 & 0.697 & 2.905 & 0.03 & 0.002 \\
\hline Residuals & 84 & 20.137 & 0.240 & & 0.74 & \\
\hline Total & 92 & 27.290 & & & 1.00 & \\
\hline Pairwise test: grou & & $F$ & & $\mathrm{R}^{2}$ & & $\mathrm{p}$ \\
\hline FF-L vs. Ref-L & & 0.803 & & 0.02 & & 0.754 \\
\hline FF-H vs. Ref-H & & 12.047 & & 0.19 & & 0.006 \\
\hline FF-L vs. FF-H & & 5.283 & & 0.10 & & 0.008 \\
\hline Ref-L vs. Ref-H & & 1.584 & & 0.04 & & 0.642 \\
\hline
\end{tabular}

Table 4. Results from SIMPER analysis of Laminaria hyperborea stipe epiphytes sampled from fish farm sites. Cumulative contribution of species up to $90 \%$ of the dissimilarities between tested group-pairs is presented, with the average biomass (standardized to $10 \mathrm{~cm}^{2}$ ungrazed stipe) for each contributing species. Bold indicates the highest biomass for each species within each group-pair. Percent in brackets refers to overall dissimilarity for the respective group-pairs (see Table S3 for species authorities)

\begin{tabular}{|lccc|}
\hline Farm effect & $\begin{array}{c}\text { Cumulative } \\
\text { contribution }\end{array}$ & \multicolumn{2}{c|}{$\begin{array}{c}\text { Average } \\
\text { biomass (g) }\end{array}$} \\
\hline FF-L vs. Ref-L (91\%) & & FF-L & Ref-L \\
Phycodrys rubens & 0.26 & $\mathbf{0 . 6 4 3}$ & 0.175 \\
Palmaria palmata & 0.47 & 0.031 & $\mathbf{1 . 9 3 5}$ \\
Bryozoa & 0.62 & $\mathbf{0 . 2 7 2}$ & 0.034 \\
Polysiphonia stricta & 0.72 & 0.051 & $\mathbf{0 . 0 8 9}$ \\
Membranoptera alata & 0.79 & $\mathbf{0 . 1 3 0}$ & 0.112 \\
Ulva lactuca & 0.83 & $\mathbf{0 . 0 6 9}$ & 0.019 \\
Delesseria sanguinea & 0.87 & $\mathbf{0 . 1 8 0}$ & 0.000 \\
Ectocarpus spp. & 0.91 & $\mathbf{0 . 0 3 3}$ & 0.002 \\
FF-H vs. Ref-H (82\%) & & FF-H & Ref-H \\
Bryozoa & 0.61 & $\mathbf{1 . 2 5 6}$ & 0.458 \\
Palmaria palmata & 0.69 & $\mathbf{0 . 4 6 8}$ & 0.013 \\
Phycodrys rubens & 0.76 & 0.046 & $\mathbf{0 . 0 6 1}$ \\
Membranoptera alata & 0.82 & $\mathbf{0 . 0 9 2}$ & 0.048 \\
Ectocarpus spp. & 0.87 & $\mathbf{0 . 2 7 8}$ & 0.018 \\
Polysiphonia stricta & 0.91 & $\mathbf{0 . 0 2 1}$ & 0.019 \\
FF-L vs. FF-H (83\%) & & FF-H & FF-L \\
Bryozoa & & $\mathbf{1 . 2 5 6}$ & 0.272 \\
Phycodrys rubens & 0.64 & 0.046 & $\mathbf{0 . 6 4 3}$ \\
Palmaria palmata & 0.71 & $\mathbf{0 . 4 6 8}$ & 0.031 \\
Membranoptera alata & 0.78 & 0.092 & $\mathbf{0 . 1 3 0}$ \\
Ectocarpus spp. & 0.83 & $\mathbf{0 . 2 7 8}$ & 0.033 \\
Delesseria sanguinea & 0.87 & 0.000 & $\mathbf{0 . 1 8 0}$ \\
Polysiphonia stricta & 0.90 & $\mathbf{0 . 0 2 1}$ & $\mathbf{0 . 0 5 1}$ \\
& & & \\
\hline
\end{tabular}

species (Palmaria palmata, Membranoptera alata, Phycodrys rubens, Polysiphonia stricta) (Table 4).

The highest amount of the variation in the epiphytic community was explained by the group factor (PERMANOVA: 13\%, Table 3). All control variables except wave exposure level were significant by PERMANOVA, although each explained only $4 \%$ or less of the community variation (Table 3 ). In the constricted 2-dimensional space, the control variables explained more of the variation in the community than the group factor (Fig. 7, Table S4).

The multivariate dispersion of the macroalgae community was significantly different between group levels (ANOVA: $F=6.64_{3,90}, \mathrm{p}<0.001$ ), with FF-H sites having the lowest dispersion (Table S5). The dispersion was also significantly different between groups when including the bryozoans (ANOVA: $F=$ 
$21.12_{3,91}, \mathrm{p}=0.010$, Fig. 7), with the high bryozoan biomass at FF-H sites (Fig. 5) further decreasing the dispersion at these sites by $30 \%$ (Table S5).

\subsection{Lamina epiphytes}

For epiphytic algal biomass on the lamina, group was a significant factor in the model ( $p=0.011$, Table 2$)$, although post hoc comparisons of farm vs. reference were insignificant (FF-H vs. Ref-L/H: $\mathrm{p}=0.304, \mathrm{FF}-\mathrm{L}$ vs. Ref-L/H: $\mathrm{p}=0.322$ ). The model predicted that farm sites would have lower levels of epiphytic algae than the reference sites if all other variables were equal. This was not apparent from a plot of epiphytes by group, which showed a trend of higher macroalgae biomass at farm sites (FF-L and FF-H; Fig. 8). The model results were most likely caused by the varying kelp density, wave exposure, and light between the sites, all of which were significantly negatively associated with epiphyte biomass (Fig. S5). Again, the importance of wave exposure level was mainly driven by the 1 high-exposure site. The epiphytic biomass was mostly made up of brown algae categorized as Ectocarpales thread (on average $77 \%$ of the lamina macroalgal epiphytes by weight).

Cover of encrusting bryozoans on the lamina (predominately Membranipora membranacea and Electra pilosa) was significantly different between group levels ( $p<0.001$, Table 2$)$. Again, the model predicted a lower cover at farm sites (Fig. S6), and kelp density was a significant factor (Table 2). FF-L had a significantly lower bryozoan cover compared to the other groups (post hoc: FF-H vs. Ref-L/H, $\mathrm{p}=0.736$; FF-L vs. Ref-L/H, $\mathrm{p}=0.011$ ), but had a higher presence of colony-forming tunicates (Fig. 8). The density
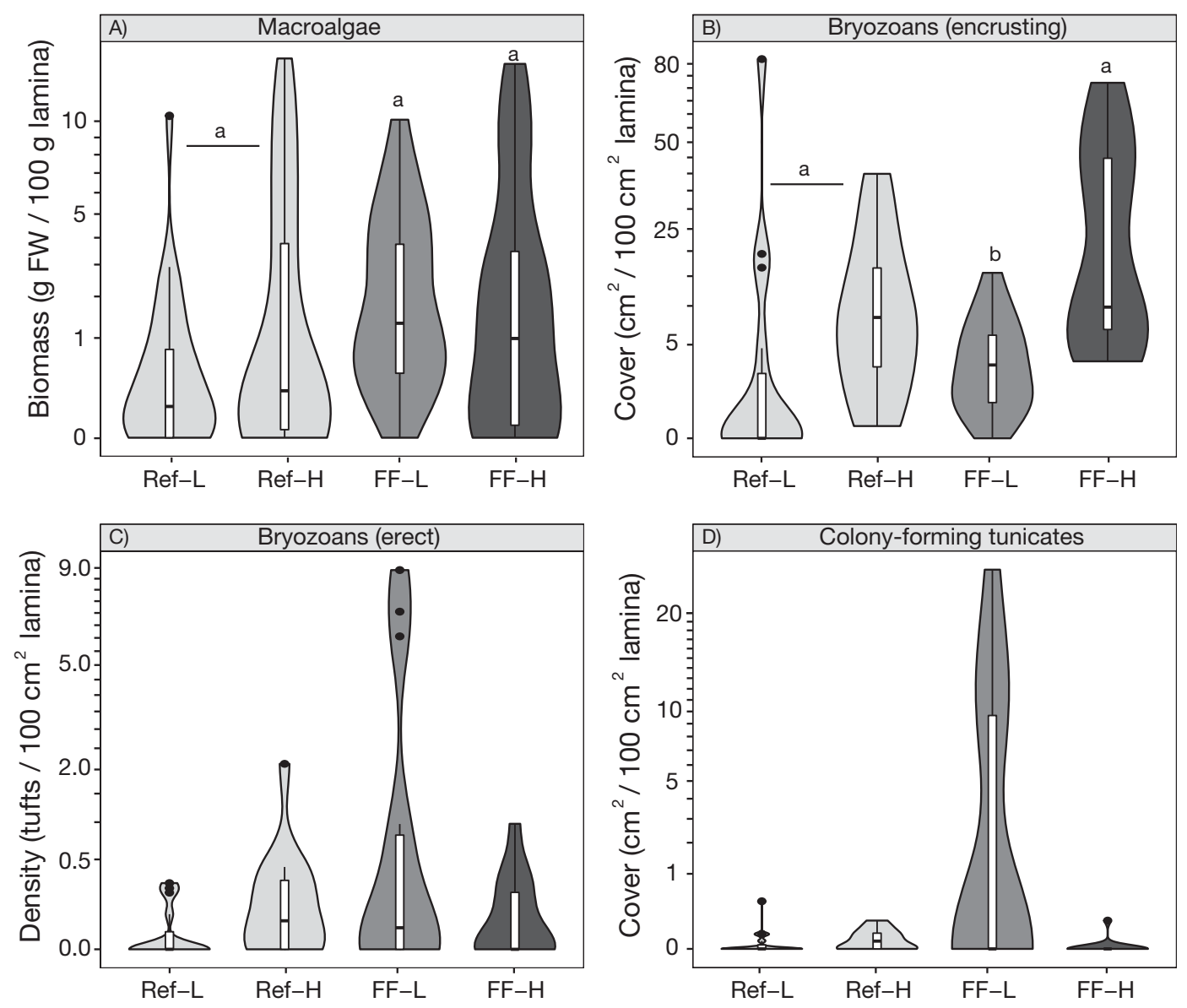

Fig. 8. Epiphytes present on Laminaria hyperborea kelp canopy laminas collected from fish farm sites (low effluent levels: FF-L; high effluent levels: FF-H) and reference sites (Ref-L, Ref-H) in the Frøya (Ref-L, FF-L) and Smøla (Ref-H, FF-H) archipelagos, Norway. (A) Algal epiphytes; (B,C) encrusting and erect bryozoans; (D) colony-forming tunicates. Note different units and use of different square-root scales on the $y$-axes. Different letters denote significant difference (Dunnett's post-hoc, $\alpha=0.05$ ). For plot explanation, see Fig. 5 
of erect bryozoan tufts (identified to Crisia spp.) was slightly higher at FF-L and Ref-H compared to FF-H and Ref-L (Fig. 8). The natural variation in epiphytic fauna was in general high and could be very variable both within and between sites.

\section{DISCUSSION}

Large-scale salmonid fish farms are increasingly situated in exposed locations where soft-bottom communities have shown high resilience to the large amounts of nutrients released (e.g. Keeley et al. 2013, 2019). However, the impact of these effluents on hardbottom communities, such as kelp forests, has received little focus. We have demonstrated that some components of the epiphytic community living on Laminaria hyperborea canopy plants are impacted by fish farming effluents in such dispersive environments. Bryozoan biomass on the kelp stipes increased with proximity to high-effluent fish farms, resulting in an altered and more homogeneous stipe community composition. The epiphyte load on the kelp lamina was impacted by wave exposure and kelp density, but a clear connection with fish farming effluents was not found. In general, natural variables, such as wave exposure, kelp age, and kelp density, had a very strong influence on variation within epiphyte communities, making further explorations of the interaction between kelp epiphytic communities and aquaculture necessary to understand the extent of the impacts.

\subsection{Stipe-associated epiphyte biomass and community structure}

The response of the stipe epiphytes to the effluent level was consistent with the expectation that dissolved nutrients and particulate matter released from fish farms may supply extra nutrition to the surrounding community. Filter feeders may be able to utilize both the dissolved nutrients and the POM released from farms, as this can increase their food supply, directly in the case of POM (Lojen et al. 2005) or via an increased abundance of phytoplankton with nutrients (Worm \& Lotze 2006). Bryozoans tend to feed on small phytoplankton (Winston 1977), and this could explain the strong association between bryozoan biomass and high effluents. Higher bryozoan cover with increasing dissolved nutrients has also been observed on seagrass Posidonia oceanica (Balata et al. 2010), but studies looking at uptake of farmderived DIN or POM for these animals is limited. Bry- ozoans (species not specified) at a seabream farm in the Red Sea took up little nitrogen from POM compared to other filter feeders (Lojen et al. 2005), but food selection and uptake rates vary between species (Winston 1977, Riisgård \& Maríquez 1997) and could therefore differ for the bryozoans in the present study.

Macroalgae can take up DIN released from farms (Carballeira et al. 2013) and incorporate ammonium (Deutsch \& Voss 2006), and it was anticipated that this should benefit small, fast-growing epiphytic algae species particularly. Although not significant at the post hoc test level, the results suggest an increase in total macroalgae biomass with effluents, in addition to the increase in filamentous opportunistic Ectocarpus spp. and a more homogeneous macroalgae community at the high-effluent sites. This is indicative of a farm impact. The predicted farm effect on local DIN levels suggests that dissolved nutrients are diluted at a much faster rate in this dispersive area compared to reports for smaller farms at less exposed locations (Sanderson et al. 2008, Jansen et al. 2018). This could explain why the trend on total macroalgae biomass was not clearer, and why the patterns within morphological and taxonomic groups were not clearly affected. The chosen methodology could also have contributed to the larger response of bryozoans compared to macroalgae; bryozoan-covered macroalgae were counted as 'Bryozoa', and therefore any extra growth of macroalgal epiphytes that later became extensively covered by bryozoans would have contributed to bryozoan differences rather than macroalgal differences. Phytoplankton may also have played a role; by having a higher growth rate than macroalgae, phytoplankton might take up DIN before the macroalgae have time to respond (Hadley et al. 2015). Higher phytoplankton biomass could potentially also benefit the bryozoans, although in this dispersive environment it is not likely that this would only benefit local bryozoan growth.

A more homogeneous epiphytic community, as observed in this study at sites exposed to high effluent levels, is a known response of communities exposed to stress, and has been reported for macroalgae communities (Oh et al. 2015) and the epiphytic community on seagrass (Balata et al. 2010). An important question following these results is how this response could affect the associated fauna. L. hyperborea forests can support over 500000 animals $\mathrm{m}^{-2}$, with a single kelp thallus supporting 80-90 faunal species on average (Christie et al. 2009). Faunal diversity and abundance in kelp forests increase with habitat diversity (Eilertsen et al. 2011, Norderhaug et al. 2014), hence lower heterogeneity could nega- 
tively affect the wide range of faunal species that depend on the kelp forest as a habitat. The change in community composition caused by the high bryozoan biomass could further alter the faunal composition of kelp forests, as mobile fauna are well known to be affected by the community structure of different macroalgae habitats (e.g. Wikström \& Kautsky 2007). Some faunal species also have preferences for epiphytic algae with specific morphologies, influenced by characteristics such as interstitial space, surface, and colour (Hacker \& Steneck 1990, Norderhaug 2004, Christie et al. 2007, 2009, Eilertsen et al. 2011), hence algae encrusted with bryozoans may be less favourable for such faunal species. The changes caused by farm effluents could thus have implications for the mobility patterns of the faunal community that directly depends on the stipe community. This in turn could affect the food availability for higher trophic levels, such as the economically important Atlantic cod Gadus morhua, saithe Pollachius virens, and seabirds that forage in the kelp forest (Fredriksen 2003, Norderhaug et al. 2005).

The impacts on community and bryozoan biomass were found at the sites where the fish farms were at the end of their production cycle (FF-H). This could indicate that this effect was short-term and that epiphyte presence and biomass can respond quickly to effluent levels within a year. Compared to that seen in benthic soft-bottom macrofaunal communities exposed to fish farm effluents, this would be a faster response (Macleod et al. 2004, Keeley et al. 2019). This could imply that $L$. hyperborea forest as habitat is more resilient to fish farming than other systems. The natural seasonal fluctuation in epiphytic biomass, which peaks in the summer and decreases in winter (Whittick 1983) could mediate recovery. It is likely also related to the dispersive nature of the study area, as more dispersive sites generally show higher resilience (Keeley et al. 2013, Valdemarsen et al. 2015). Recovery speed should be further explored, e.g. by including samples from farms at the end of their fallowing period, or examining areas where farms are being moved.

Factors other than farm effluents also play a role in epiphyte abundance and composition. Wave exposure and kelp age are reported to positively affect stipe epiphyte density (Norderhaug et al. 2012, Bekkby et al. 2015, Steen et al. 2016) and composition (Pedersen et al. 2014), which was mostly supported by our results for both macroalgae and bryozoans (depending on the inclusion of the highexposure site; Table 2). The total stipe epiphytic biomass reported here was low compared to other reports for L. hyperborea stipes (Norton et al. 1977, Whittick
1983, Steen et al. 2016), most likely caused by the observed high grazing activity in the study area. Large grazing fronts of the sea urchin Echinus esculentus (Linnaeus, 1758) were regularly observed and are known to feed on algae and associated epiphytes (Jorde \& Klavestad 1963, Comely \& Ansell 1988). Sea urchins can also exploit and assimilate farm waste (White et al. 2017, 2018), and may benefit from intensive farming. This is a potential ecological factor that was not within the scope of this study but needs to be further examined. The grazing may have affected our results in 2 ways. As L. hyperborea stipe communities show vertical zonation (Whittick 1983, Christie et al. 2007), the upper-stipe epiphyte community could have been disproportionately represented in this study (as the lower part of stipes were often grazed). However, this is unlikely to have affected the main results, as these zonation patterns have only been reported for rhodophytes, and not for bryozoans and Ectocarpus spp. Secondly, during shortterm increases in nutrients, grazing can mediate the growth of epiphytes (Balata et al. 2010) and macroalgae communities (Karez et al. 2004, Russell \& Connell 2007). Top-down control of epiphytes via grazing could therefore have limited any epiphyte biomass increase in response to farm effluents, making impacts harder to detect. Given this, the low level of replication at the site level in this study $(n=3)$, and the substantial influence of natural variables on epiphyte communities, our detection of a significant relationship between fish farm effluents and kelp epiphytes is highly noteworthy.

\subsection{Lamina epiphytes}

In contrast to the stipe, there were no significant increases in lamina-associated epiphyte abundance that could be related to nutrients from fish farming, suggesting that the kelp lamina could be more resilient to an increased epiphyte load than the kelp stipe in dispersive environments. For the range of wave exposure levels modelled at our sampling sites, lamina epiphyte load decreases with exposure (Pedersen et al. 2012), which could contribute to this potential higher resilience. The way nutrients are released from fish farms could also have contributed to the lack of a clear response. Along the southern coast of Australia, macroalgal epiphyte load on lamina of the kelp Ecklonia radiata increased significantly under high and constant nitrogen conditions (1.8 times higher than ambient waters) (Russell et al. 2005). The elevation in nutrient levels was compara- 
ble to the maximum that was predicted at the higheffluent farm sites herein, but the contrasting results could be related to the nature of nutrient pulses from fish farms. Longer, constant nitrogen pulses have a higher impact on epiphytic communities than several shorter-duration pulses (Worm \& Sommer 2000), and the nitrogen plume from fish farms would be much more variable compared to the artificial nutrient source used by Russell et al. (2005). However, the dominant lamina epiphytes were thread-forming Ectocarpales algae, thus including the stipe algae (Ectocarpus spp.) that were found to respond to farm effluents. The differing response of the epiphytic algae herein compared to that observed on E. radiata could also be related to oligotrophic conditions at the Australian study sites (Russell et al. 2005), different levels of wave exposure (not reported for Australian sites), or different anti-fouling mechanisms between the 2 kelp species (reviewed by Bartsch et al. 2008).

The lowest cover of encrusting lamina bryozoans was found at the sites with low-effluent fish farming. However, a higher cover of colony-forming tunicates was observed at these sites, which could indicate competition for space between epiphytic invertebrates. Competition for space between colony-forming invertebrates on host plants is common (Boaden et al. 1976, O'Connor et al. 1980). Other factors not examined in the present study could also have played a role in epiphyte abundance, for example, the growth rate of kelp (Andersen et al. 2011) or grazer density (Worm \& Lotze 2006, Balata et al. 2010). In addition, both lamina bryozoans and epiphytes showed a negative relationship with kelp density. One potential explanation for this relationship is that higher kelp density could directly reduce epiphyte settlement via increased mechanical abrasion by sweeping laminas, as shown for settlement of sessile invertebrates in the understorey community (Jenkins et al. 1999, Connell 2003). Sampling time could also have had an effect; sampling was conducted in August, and a higher lamina epiphyte diversity is present in May compared to August for kelp species Saccharina latissima and Laminaria digitata (Carlsen et al. 2007), and this could also be true for L. hyperborea. Hence, sampling laminas earlier in the summer could have yielded different results.

The epiphytic kelp community documented in this study was highly variable both within and between sites at small scales, as has also been found in previous work (Karez et al. 2004, Oh et al. 2015). For impact studies, this means that a high number of sites are needed to detect impacts, especially when abiotic and biotic factors, which can also affect the community, vary between sites. Although we sampled from rela- tively many sites for this type of study and a number of factors could be controlled for (e.g. the abiotic modelled factors, kelp density, depth), the resolution of the abiotic modelled factors could miss smallscale variations that influence the kelp community.

\subsection{Future perspectives}

Changes in epiphytic communities on perennial algae can be seen as early warning signs of eutrophication (Balata et al. 2010) and can, over time, be followed by a degradation of the perennial species itself (e.g. Worm \& Sommer 2000). Eutrophication has been a driver implicated in shifts from kelp forests to ephemeral algae communities along the coasts of Norway, Australia, Brazil, Russia, and in the Mediterranean (Filbee-Dexter \& Wernberg 2018), although the mechanisms behind these shifts can be complex and hard to discern. The natural variation is high in these communities, which often requires a rigorous sampling regime to be able to identify real changes. At the level of sampling conducted herein, impacts from nutrients were found on the epiphytic stipe community, which could have implications for the fauna associated with this habitat and should be further explored. More knowledge on the interaction between kelp density and lamina epiphytes could also further our understanding of the mechanism(s) behind degradation of kelp forests seen worldwide. Although no increase in lamina epiphytes was detected with increasing fish farm effluents, elevated nutrients derived from fish farming may interact with other stressors in unpredictable ways. Climate change is one potential stressor, as higher temperatures have negative impacts on kelp (Araújo et al. 2016, Krumhansl et al. 2016) while promoting recruitment and growth rates of bryozoans such as $M$. membranacea (Saunders \& Metaxas 2008, Scheibling \& Gagnon 2009). The fishfarming industry is expected to expand quickly in the future, both in Norway (NFD 2014) and globally (FAO 2018), and dispersive coastal sites will most likely be favoured due to their higher resilience. More understanding of the interactions between kelp forest and nutrients from aquaculture is needed to be able to monitor, detect potential changes, and underpin good management of kelp forest ecosystems in the future.

Acknowledgements. This study was financially supported by the Norwegian Research Council (Project number 228871) with additional in-kind support from SalMar ASA. We are grateful for field assistance provided by Siri Olsen and lab assistance by Marita Larsen, and thank the 4 anonymous reviewers for comments that greatly improved this manuscript. 


\section{LITERATURE CITED}

Ådlandsvik B (2019) LADiM documentation. https://ladim. readthedocs.io

Albretsen J, Sperrevik AK, Staalstrøm A, Sandvik AD, Vikebø D, Asplin L (2011) Norkyst-800 Report No. 1: User manual and technical descriptions, Fisken og Havet No. 2/2011. Institute of Marine Research, Bergen

* Andersen GS, Steen H, Christie H, Fredriksen S, Moy FE (2011) Seasonal patterns of sporophyte growth, fertility, fouling, and mortality of Saccharina latissima in Skagerrak, Norway: implications for forest recovery. J Mar Biol 2011:690375

Andersen GS, Moy FE, Christie H (2019) In a squeeze: epibiosis may affect the distribution of kelp forests. Ecol Evol 9:2883-2897

Araújo RM, Assis J, Aguillar R, Airoldi L and others (2016) Status, trends and drivers of kelp forests in Europe: an expert assessment. Biodivers Conserv 25:1319-1348

Armitage CS, Sjøtun K (2016) Epiphytic macroalgae mediate the impact of a non-native alga on associated fauna. Hydrobiologia 776:35-49

Asplin L, Johnsen I, Sandvik A, Albretsen J, Sundfjord V, Aure J, Boxaspen K (2014) Dispersion of salmon lice in the Hardangerfjord. Mar Biol Res 10:216-225

Asplin L, Albretsen J, Johnsen I, Sandvik A (2020) The hydrodynamic foundation for salmon-lice dispersion modeling along the Norwegian coast. Ocean Dyn 70:1151-1167

Balata D, Piazzi L, Nesti U, Bulleri F, Bertocci I (2010) Effects of enhanced loads of nutrients on epiphytes on leaves and rhizomes of Posidonia oceanica. J Sea Res 63:173-179

*Bannister RJ, Johnsen IA, Hansen PK, Kutti T, Asplin L (2016) Near-and far-field dispersal modelling of organic waste from Atlantic salmon aquaculture in fjord systems. ICES J Mar Sci 73:2408-2419

Bartsch I, Wiencke C, Bischof K, Buchholz CM and others (2008) The genus Laminaria sensu lato: recent insights and developments. Eur J Phycol 43:1-86

Bekkby T, Rinde E, Erikstad L, Bakkestuen V (2009) Spatial predictive distribution modelling of the kelp species Laminaria hyperborea. ICES J Mar Sci 66:2106-2115

Bekkby T, Moy FE, Olsen H, Rinde E and others (2013) The Norwegian programme for mapping of marine habitats - providing knowledge and maps for ICZMP. In: Moksness E, Dahl E, Støttrup J (eds) Global challenges in integrated coastal zone management, Vol II. John Wiley and Sons, Oxford, p 19-30

Bekkby T, Angeltveit G, Gundersen H, Tveiten L, Norderhaug KM (2015) Red sea urchins (Echinus esculentus) and water flow influence epiphytic macroalgae density. Mar Biol Res 11:375-384

Bergheim A, Braaten B (2007) Modell for utslipp fra norske matfiskanlegg til sjø [Model for emissions from Norwegian fish farming to the ocean]. Report 2007/180, IRIS, Stavanger

Boaden PJS, O'Connor RJ, Seed R (1976) The fauna of a Fucus serratus L. community: ecological isolation in sponges and tunicates. J Exp Mar Biol Ecol 21:249-267

Brodie J, Maggs CA, John DM (2007) Green seaweeds of Britain and Ireland. British Phycological Society, London

* Carballeira C, Viana IG, Carballeira A (2013) $\delta^{15} \mathrm{~N}$ values of macroalgae as an indicator of the potential presence of waste disposal from land-based marine fish farms. J Appl Phycol 25:97-107

Carlsen BP, Johnsen G, Berge J, Kuklinski P (2007) Biodiver- sity patterns of macro-epifauna on different lamina parts of Laminaria digitata and Saccharina latissima collected during spring and summer 2004 in Kongsfjorden, Svalbard. Polar Biol 30:939-943

Carvajalino-Fernández MA, Keeley NB, Fer I, Law BA, Bannister RJ (2020) Effect of substrate type and pellet age on the resuspension of Atlantic salmon faecal material. Aquacult Environ Interact 12:117-129

Charpy-Roubaud C, Sournia A (1990) The comparative estimation of phytoplanktonic, microphytobenthic and macrophytobenthic primary production in the oceans. Mar Microb Food Webs 4:31-57

Christie H, Jørgensen NM, Norderhaug KM, WaageNielsen E (2003) Species distribution and habitat exploitation of fauna associated with kelp (Laminaria hyperborea) along the Norwegian coast. J Mar Biol Assoc UK 83:687-699

Christie H, Jørgensen NM, Norderhaug KM (2007) Bushy or smooth, high or low; importance of habitat architecture and vertical position for distribution of fauna on kelp. J Sea Res 58:198-208

* Christie H, Norderhaug KM, Fredriksen S (2009) Macrophytes as habitat for fauna. Mar Ecol Prog Ser 396:221-233

Clarke KR, Warwick RR (2001) Change in marine communities: an approach to statistical analysis and interpretation. Primer-E, Plymouth

* Comely C, Ansell A (1988) Population density and growth of Echinus esculentus L. on the Scottish west coast. Estuar Coast Shelf Sci 27:311-334

Connell SD (2003) Negative effects overpower the positive of kelp to exclude invertebrates from the understorey community. Oecologia 137:97-103

* Davies CE, Moss D, Hill MO (2004) EUNIS habitat classification, revised 2004. Report to European Environment Agency, European Topic Centre on Nature Protection and Biodiversity. October 2004. https://www. eea.europa.eu/data-and-maps/data/eunis-habitatclassification/documentation/eunis-2004-report.pdf

*Deutsch B, Voss M (2006) Anthropogenic nitrogen input traced by means of $\delta^{15} \mathrm{~N}$ values in macroalgae: results from in-situ incubation experiments. Sci Total Environ 366:799-808

Dixon PS, Irvine LM (1977) Seaweeds of the British Isles, Vol 1. Rhodophyta. Part 1. Introduction, Nemaliales, Gigartinales. The Natural History Museum, London

*Eilertsen M, Norderhaug KM, Sjøtun K (2011) Does the amphipod fauna associated with epiphytes on kelp (Laminaria hyperborea) change with depth? Mar Biol Res 7:224-234

Eriksson BK, Sandström A, Isæus M, Schreiber H, Karås P (2004) Effects of boating activities on aquatic vegetation in the Stockholm archipelago, Baltic Sea. Estuar Coast Shelf Sci 61:339-349

FAO (2018) The state of world fisheries and aquaculture 2018-Meeting the sustainable development goals. FAO, Rome

Filbee-Dexter K, Wernberg T (2018) Rise of turfs: a new battlefront for globally declining kelp forests. Bioscience 68:64-76

FFiskeridirektoratet (2019) Statistics aquaculture - biomass statistics. https://www.fiskeridir.no/Akvakultur/Statistikkakvakultur/Biomassestatistikk (accessed 23 February 2019)

Fletcher RL (1987) Seaweeds of the British Isles. 3. Fucophyceae (Phaeophyceae). Part 1. British Museum (Natural History), London 
Fredriksen S (2003) Food web studies in a Norwegian kelp forest based on stable isotope $\left(\delta^{13} \mathrm{C}\right.$ and $\left.\delta^{15} \mathrm{~N}\right)$ analysis. Mar Ecol Prog Ser 260:71-81

Gullestad P, Bjørgo S, Eithun I, Ervik A and others (2011) Effektiv og bærekraftig arealbruk i havbruksnæringen areal til begjær [Efficient and sustainable use of area in the aquaculture industry]. Rapport fra Ekspertutvalget til Fiskeri- og Kystdepartementet. https://www.regjeringen. no/globalassets/upload/fkd/vedlegg/rapporter/2011/ effektiv_og_baerekraftig_arealbruk_i_havbruksnaeringen .pdf

G Gundersen H, Bekkby T, Norderhaug KM, Oug E, Rinde E, Fredriksen F (2018) Stortareskog i Norskehavet og Barentshavet, marint gruntvann. Norsk rødliste for naturtyper 2018. [Laminaria hyperborea forest in the Norwegian Sea and Barents Sea, Marine shallow waters. Norwegian red list for habitats 2018]. Artsdatabanken, Trondheim. https://artsdatabanken.no/RLN2018/343 (accessed 14 February 2019)

Hacker SD, Steneck RS (1990) Habitat architecture and the abundance and body-size-dependent habitat selection of a phytal amphipod. Ecology 71:2269-2285

Hadley C, Wild-Allen K, Johnson C, Macleod C (2015) Modeling macroalgae growth and nutrient dynamics for integrated multi-trophic aquaculture. J Appl Phycol 27: 901-916

* Hansen PK (2019) Miljøpåvirkning på bunn som følge av partikulære organiske utslipp fra fiskeoppdrett [Benthic environmental impacts following the release of particulate organic matter from fish farming]. In: Grefsrud ES, Svåsand T, Glover K, Husa V and others (eds) Risikorapport norsk fiskeoppdrett 2019 [Risk assessment of Norwegian fin fish aquaculture 2019]. Fisken og havet, særnr. 5-2019, Institute of Marine Research, Bergen, p 43-56. https://www.hi.no/hi/nettrapporter/fisken-og-havet-20195

Hjøllo SS, Skogen MD, Svendsen E (2009) Exploring currents and heat within the North Sea using a numerical model. J Mar Syst 78:180-192

Holmer M (2010) Environmental issues of fish farming in offshore waters: perspectives, concerns and research needs. Aquacult Environ Interact 1:57-70

Howarth RW, Marino R (2006) Nitrogen as the limiting nutrient for eutrophication in coastal marine ecosystems: evolving views over three decades. Limnol Oceanogr 51: 364-376

*Husa V (2019) Miljøeffekter som følge av utslipp av løste næringssalter fra fiskeoppdrett [Environmental impacts following the release of dissolved nutrients from fish farming]. In: Grefsrud ES, Svåsand T, Glover K, Husa V and others (eds) Risikorapport norsk fiskeoppdrett 2019 [Risk assessment of Norwegian fin fish aquaculture 2019]. Fisken og havet, særnr. 5-2019, Institute of Marine Research, Bergen, p 43-56. https://www.hi.no/hi/ nettrapporter/fisken-og-havet-2019-5

Husa V, Bannister R, Hansen PK, Kutti T, Jakobsen HR, Aure J (2016) Utslipp av partikulære og løste stoffer fra matfiskanlegg [Release of particulate and dissolved nutrients from fish farming]. In: Svåsand T, Karlsen $\varnothing$, Kvamme BO, Stien LH, Taranger GL, Boxaspen KK (eds) Risikorapport norsk fiskeoppdrett [Risk assessment of Norwegian fin fish aquaculture 2016]. Fisken og havet, særnr. 2-2016. Institute of Marine Research, Bergen, p 109-128. https://www.hi.no/hi/nettrapporter/risikorapport-norskfiskeoppdrett/2016/risikovurdering_2016
IMR (Institute of Marine Research) (2017) Forskningsdata [Research data] https://www.hi.no/hi/forskning/marinedata-forskningsdata/overvaking-av-fysisk-og-kjemiskmiljo (accessed 10 January 2019)

Irvine LM (1983) Seaweeds of the British Isles, Vol 1. Rhodophyta. Part 2A. Cryptonemiales (sensu stricto), Palmariales, Rhodymeniales. The Natural History Museum, London

Irvine LM, Chamberlain YM (1994) Seaweeds of the British Isles, Vol 1. Rhodophyta. Part 2B. Corallinales, Hildenbrandiales. The Natural History Museum, London

Isæus M (2004) Factors structuring Fucus communities at open and complex coastlines in the Baltic Sea. PhD dissertation, Stockholm University

Jansen HM, Reid GK, Bannister RJ, Husa V and others (2016) Discrete water quality sampling at open-water aquaculture sites: limitations and strategies. Aquacult Enviro n Interact 8:463-480

Jansen HM, Broch OJ, Bannister R, Cranford P and others (2018) Spatio-temporal dynamics in the dissolved nutrient waste plume from Norwegian salmon cage aquaculture. Aquacult Environ Interact 10:385-399

Jenkins SR, Norton TA, Hawkins SJ (1999) Settlement and post-settlement interactions between Semibalanus balanoides (L.)(Crustacea: Cirripedia) and three species of fucoid canopy algae. J Exp Mar Biol Ecol 236:49-67

Jorde I (1966) Algal associations of a coastal area south of Bergen, Norway. Sarsia 23:1-52

Jorde I, Klavestad N (1963) The natural history of the Hardangerfjord: 4 . The benthonic algal vegetation. Sarsia 9:1-99

Kain JM (1963) Aspects of the biology of Laminaria hyperborea: II. Age, weight and length. J Mar Biol Assoc UK 43:129-151

Kain JM (1977) The biology of Laminaria hyperborea X. The effect of depth on some populations. J Mar Biol Assoc UK 57:587-607

Kain JM (1979) A view of the genus Laminaria. Oceanogr Mar Biol Annu Rev 17:101-161

Kain JM (1989) The seasons in the subtidal. Br Phycol J 24: 203-215

KKarez R, Engelbert S, Kraufvelin P, Pedersen MF, Sommer U (2004) Biomass response and changes in composition of ephemeral macroalgal assemblages along an experimental gradient of nutrient enrichment. Aquat Bot 78 : 103-117

Keeley NB, Forrest BM, Macleod CK (2013) Novel observations of benthic enrichment in contrasting flow regimes with implications for marine farm monitoring and management. Mar Pollut Bull 66:105-116

KKeeley N, Valdemarsen T, Woodcock S, Holmer M, Husa V, Bannister R (2019) Resilience of dynamic coastal benthic ecosystems in response to large-scale finfish farming. Aquacult Environ Interact 11:161-179

Kraufvelin P, Moy FE, Christie H, Bokn TL (2006) Nutrient addition to experimental rocky shore communities revisited: delayed responses, rapid recovery. Ecosystems 9: 1076-1093

Krumhansl KA, Scheibling RE (2012) Production and fate of kelp detritus. Mar Ecol Prog Ser 467:281-302

* Krumhansl KA, Lee JM, Scheibling RE (2011) Grazing damage and encrustation by an invasive bryozoan reduce the ability of kelps to withstand breakage by waves. J Exp Mar Biol Ecol 407:12-18

Krumhansl KA, Okamoto DK, Rassweiler A, Novak M and others (2016) Global patterns of kelp forest change over 
the past half-century. Proc Natl Acad Sci USA 113: 13785-13790

Kutti T, Ervik A, Hansen PK (2007a) Effects of organic effluents from a salmon farm on a fjord system. I. Vertical export and dispersal processes. Aquaculture 262:367-381

Kutti T, Hansen PK, Ervik A, Høisæter T, Johannessen P (2007b) Effects of organic effluents from a salmon farm on a fjord system. II. Temporal and spatial patterns in infauna community composition. Aquaculture 262:355-366

* Lenth RV (2016) lsmeans: least-squares means. R package version 2.30-0. https://CRAN.R-project.org/package $=$ lsmeans

Levin PS, Coyer JA, Petrik R, Good TP (2002) Communitywide effects of nonindigenous species on temperate rocky reefs. Ecology 83:3182-3193

Lojen S, Spanier E, Tsemel A, Kats T, Eden N, Angel DL (2005) $\delta^{15} \mathrm{~N}$ as a natural tracer of particulate nitrogen effluents released from marine aquaculture. Mar Biol 148: 87-96

Lüning K (1990) Seaweeds: their environment, biogeography and ecophysiology. John Wiley \& Sons Inc., New York, NY

* Macleod CK, Crawford CM, Moltschaniwskyj NA (2004) Assessment of long term change in sediment condition after organic enrichment: defining recovery. Mar Pollut Bull 49:79-88

Maggs CA, Hommersand MH (1993) Seaweeds of the British Isles, Vol 1. Rhodophyta. Part 3A. Ceramiales. The Natural History Museum, London

Martinez Arbizu P (2017) pairwiseAdonis: pairwise multilevel comparison using adonis. R package version 0.0.1. https://github.com/pmartinezarbizu/pairwiseAdonis\#\#\#\#

Norderhaug KM (2004) Use of red algae as hosts by kelpassociated amphipods. Mar Biol 144:225-230

*Norderhaug KM, Fredriksen S, Nygaard K (2003) Trophic importance of Laminaria hyperborea to kelp forest consumers and the importance of bacterial degradation to food quality. Mar Ecol Prog Ser 255:135-144

Norderhaug KM, Christie H, Fosså J, Fredriksen S (2005) Fish-macrofauna interactions in a kelp (Laminaria hyperborea) forest. J Mar Biol Assoc UK 85:1279-1286

Norderhaug KM, Christie H, Andersen GS, Bekkby T (2012) Does the diversity of kelp forest macrofauna increase with wave exposure? J Sea Res 69:36-42

*Norderhaug KM, Christie H, Rinde E, Gundersen H, Bekkby $\mathrm{T}$ (2014) Importance of wave and current exposure to fauna communities in Laminaria hyperborea kelp forests. Mar Ecol Prog Ser 502:295-301

Norton T, Hiscock K, Kitching J (1977) The ecology of Lough Ine: XX. The Laminaria forest at Carrigathorna. J Ecol 65:919-941

Norwegian Ministry of Trade, Industry and Fisheries (NFD) (2014) Forutsigbar og miljømessig bærekraftig vekst i norsk lakse- og ørretoppdrett [Predictable and environmentally sustainable growth in Norwegian salmon- and trout farming]. Meld St 16. https://www.regjeringen.no/ no/dokumenter/meld.-st.-16-2014-2015/id2401865/? ch=1

' O'Connor RJ, Seed R, Boaden PJS (1980) Resource space partitioning by the Bryozoa of a Fucus serratus L. community. J Exp Mar Biol Ecol 45:117-137

* Oh ES, Edgar GJ, Kirkpatrick JB, Stuart-Smith RD, Barrett NS (2015) Broad-scale impacts of salmon farms on temperate macroalgal assemblages on rocky reefs. Mar Pollut Bull 98:201-209

Økland T (1990) Vegetational and ecological monitoring of boreal forests in Norway I. Rausjømarka in Akershus county, SE Norway. Sommerfeltia 10:1-52

Økland T (1996) Vegetation-environment relationships of boreal spruce forests in ten monitoring reference areas in Norway. Sommerfeltia 22:1-349

* Oksanen J, Blanchet FG, Friendly M, Kindt R and others (2018) vegan: Community ecology package. R package version 2.5-2. https://CRAN.R-project.org/package=vegan

* Parker KC (1988) Environmental relationships and vegetation associates of columnar cacti in the northern Sonoran Desert. Vegetatio 78:125-140

* Pedersen MF, Borum J (1996) Nutrient control of algal growth in estuarine waters. Nutrient limitation and the importance of nitrogen requirements and nitrogen storage among phytoplankton and species of macroalgae. Mar Ecol Prog Ser 142:261-272

* Pedersen MF, Nejrup LB, Fredriksen S, Christie H, Norderhaug KM (2012) Effects of wave exposure on population structure, demography, biomass and productivity of the kelp Laminaria hyperborea. Mar Ecol Prog Ser 451: 45-60

* Pedersen MF, Nejrup LB, Pedersen TM, Fredriksen S (2014) Sub-canopy light conditions only allow low annual net productivity of epiphytic algae on kelp Laminaria hyperborea. Mar Ecol Prog Ser 516:163-176

*Pedersen MF, Filbee-Dexter K, Norderhaug KM, Fredriksen S, Frisk NL, Fagerli CW, Wernberg T (2020) Detrital carbon production and export in high latitude kelp forests. Oecologia 192:227-239

* Pinheiro J, Bates D, DebRoy S, Sarkar D, R Core Team (2017) nlme: linear and nonlinear mixed effects models. R package version 3.1-131. https://CRAN.R-project.org/ package $=$ nlme

Prud'homme van Reine WF (1982) Taxonomic revision of the European Sphacelariaceae (Sphacelariales, Phaeophyceae). Leiden Bot Ser 6:3-293

R Core Team (2017) R: a language and environment for statistical computing, v. 3.3.1. R Foundation for Statistical Computing, Vienna

Rey F (2004) Phytoplankton of the sea. In: Skjoldal HR (ed) The Norwegian Sea ecosystem. Tapir Academic Press, Trondheim, p 97-136

* Riisgård HU, Maríquez P (1997) Filter-feeding in fifteen marine ectoprocts (Bryozoa): particle capture and water pumping. Mar Ecol Prog Ser 154:223-239

* Rönnberg O, Ådjers K, Ruokolahti C, Bondestam M (1992) Effects of fish farming on growth, epiphytes and nutrient content of Fucus vesiculosus L. in the Åland archipelago, northern Baltic Sea. Aquat Bot 42:109-120

Rueness J (1977) Norsk algeflora. Universitetsforlaget, Oslo * Russell BD, Connell SD (2007) Response of grazers to sudden nutrient pulses in oligotrophic versus eutrophic conditions. Mar Ecol Prog Ser 349:73-80

* Russell BD, Elsdon TS, Gillanders BM, Connell SD (2005) Nutrients increase epiphyte loads: broadscale observations and an experimental assessment. Mar Biol 147:551-558

* Sanderson J, Cromey C, Dring M, Kelly MS (2008) Distribution of nutrients for seaweed cultivation around salmon cages at farm sites in north-west Scotland. Aquaculture 278:60-68

* Saunders M, Metaxas A (2008) High recruitment of the introduced bryozoan Membranipora membranacea is associated with kelp bed defoliation in Nova Scotia, Canada. Mar Ecol Prog Ser 369:139-151

* Scheibling RE, Gagnon P (2009) Temperature-mediated outbreak dynamics of the invasive bryozoan Membrani- 
pora membranacea in Nova Scotian kelp beds. Mar Ecol Prog Ser 390:1-13

Schneider CA, Rasband WS, Eliceiri KW (2012) NIH image to ImageJ: 25 years of image analysis. Nat Methods 9: 671-675

Selvik JR, Sample JE (2018) Kildefordelte tilførsler av nitrogen og fosfor til norske kystområder i 2017 - tabeller, figurer og kart [Source appointed input of nitrogen and phosphorus to Norwegian coastal areas in 2017 - tables, figures and maps]. NIVA report 7312-2018. http://hdl. handle.net/11250/2583880

Shchepetkin AF, McWilliams JC (2005) The regional oceanic modeling system (ROMS): a split-explicit, free-surface, topography-following-coordinate oceanic model. Ocean Model 9:347-404

Skogen MD, Søiland H (1998) A user's guide to NORVECOM V2. 0. The norwegian ecological model system. Tech Rep. Fisken og Havet 19/98, Institute of Marine Research, Bergen. http://hdl.handle.net/11250/113623

Skogen MD, Svendsen E, Berntsen J, Aksnes D, Ulvestad KB (1995) Modelling the primary production in the North Sea using a coupled three-dimensional physical-chemicalbiological ocean model. Estuar Coast Shelf Sci 41:545-565

Skogen M, Svendsen E, Ostrowski M (1997) Quantifying volume transports during SKAGEX with the Norwegian Ecological Model system. Cont Shelf Res 17:1817-1837

Søiland H, Skogen M (2000) Validation of a 3D biophysical model using nutrient observations in the North Sea. ICES J Mar Sci 57:816-823

Steen H (2017) Tilstandsvurdering av B-felt for tarehøsting i Møre og Romsdal i 2017 [Assessment of B-fields for kelp harvesting in Møre og Romsdal in 2017]. Rep 27-2017. Institute of Marine Research, Bergen. http://hdl.handle. net/11250/2480418

Steen H (2018) Tilstandsvurdering av C-felt for tarehøsting i Sør-Trøndelag og Nord-Trøndelag i 2018 [Assessment of C-fields for kelp harvesting in Sør-Trøndelag and NordTrøndelag in 2018]. Rep 32-2018. Institute of Marine Research, Bergen. http://hdl.handle.net/11250/2570004

Steen H, Moy FE, Bodvin T, Husa V (2016) Regrowth after kelp harvesting in Nord-Trøndelag, Norway. ICES J Mar Sci 73:2708-2720

Steneck RS, Graham MH, Bourque BJ, Corbett D, Erlandson JM, Ester JA, Tegner MJ (2002) Kelp forest ecosystems: biodiversity, stability, resilience and future. Environ Conserv 29:436-459

Teagle H, Hawkins SJ, Moore PJ, Smale DA (2017) The role

Editorial responsibility: Alejandro Buschmann,

Puerto Montt, Chile

Reviewed by: 4 anonymous referees of kelp species as biogenic habitat formers in coastal marine ecosystems. J Exp Mar Biol Ecol 492:81-98

*Valdemarsen T, Hansen PK, Ervik A, Bannister RJ (2015) Impact of deep-water fish farms on benthic macrofauna communities under different hydrodynamic conditions. Mar Pollut Bull 101:776-783

*Wang X, Olsen LM, Reitan KI, Olsen Y (2012) Discharge of nutrient wastes from salmon farms: environmental effects, and potential for integrated multi-trophic aquaculture. Aquacult Environ Interact 2:267-283

White CA, Bannister RJ, Dworjanyn SA, Husa V, Nichols PD, Kutti T, Dempster T (2017) Consumption of aquaculture waste affects the fatty acid metabolism of a benthic invertebrate. Sci Total Environ 586:1170-1181

*White CA, Bannister R, Dworjanyn SA, Husa V, Nichols PD, Dempster T (2018) Aquaculture-derived trophic subsidy boosts populations of an ecosystem engineer. Aquacult Environ Interact 10:279-289

Whittick A (1983) Spatial and temporal distributions of dominant epiphytes on the stipes of Laminaria hyperborea (Gunn.) Fosl. (Phaeophyta: Laminariales) in SE Scotland. J Exp Mar Biol Ecol 73:1-10

Wickham H (2016) ggplot2: Elegant graphics for data analysis. R package version 2.2.1. https://CRAN.R-project.org/ package $=$ ggplot 2

Wijkmark N, Isæus M (2010) Wave exposure calculations for the Baltic Sea. AquaBiota report 2012:2, AquaBiota Water Research, Stockholm. https://www.aquabiota.se/ wp-content/uploads/ABWR_Report_2010_02_BaltExp.pdf

*Wikström SA, Kautsky L (2007) Structure and diversity of invertebrate communities in the presence and absence of canopy-forming Fucus vesiculosus in the Baltic Sea. Estuar Coast Shelf Sci 72:168-176

Winston JE (1977) Feeding in marine bryozoans. In: Woollacott RM, Zimmer RL (eds) Biology of bryozoans. Academic Press, New York, NY, p 233-272

W Worm B, Lotze HK (2006) Effects of eutrophication, grazing, and algal blooms on rocky shores. Limnol Oceanogr 51: $569-579$

*Worm B, Sommer U (2000) Rapid direct and indirect effects of a single nutrient pulse in a seaweed-epiphyte-grazer system. Mar Ecol Prog Ser 202:283-288

Xu R (2003) Measuring explained variation in linear mixed effects models. Stat Med 22:3527-3541

Zuur AF, Ieno EN, Walker NJ, Saveliev AA, Smith GM (2009) Mixed effects models and extensions in ecology with R. Springer, New York, NY

Submitted: February 23, 2020

Accepted: December 29, 2020

Proofs received from author(s): March 9, 2021 